(2) norden 



\section{Food Labelling}

Nordic Consumers’ Attitudes to Food Labelling

TemaNord 2007:513 


\section{Food Labelling}

Nordic Consumers' Attitudes to Food Labelling

TemaNord 2007:513

(C) Nordic Council of Ministers, Copenhagen 2007

ISBN 978-92-893-1460-2

Print: Ekspressen Tryk \& Kopicenter

Copies: 190

Printed on environmentally friendly paper

This publication can be ordered on www.norden.org/order. Other Nordic publications are available at www.norden.org/publications

Printed in Denmark

Nordic Council of Ministers

Store Strandstræde 18

DK-1255 Copenhagen K

Phone (+45) 33960200

Fax (+45) 33960202

www.norden.org

\section{Nordic Council}

Store Strandstræde 18

DK-1255 Copenhagen K

Phone (+45) 33960400

Fax (+45) 33111870

\section{Nordic co-operation}

Nordic cooperation is one of the world's most extensive forms of regional collaboration, involving Denmark, Finland, Iceland, Norway, Sweden, and three autonomous areas: the Faroe Islands, Greenland, and Åland.

Nordic cooperation has firm traditions in politics, the economy, and culture. It plays an important rol in European and international collaboration, and aims at creating a strong Nordic community in a strong Europe.

Nordic cooperation seeks to safeguard Nordic and regional interests and principles in the global community. Common Nordic values help the region solidify its position as one of the world's most innovative and competitive. 


\section{Content}

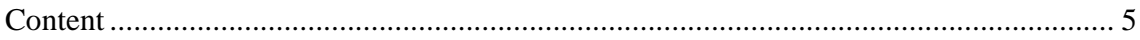

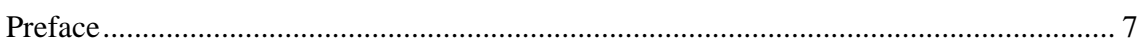

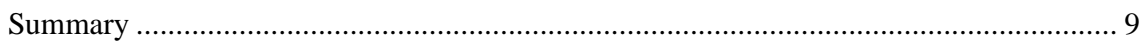

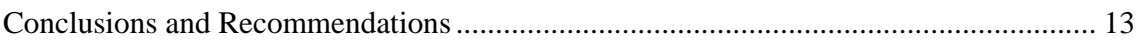

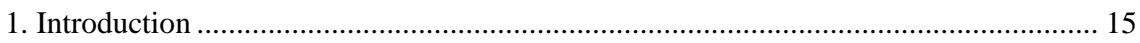

2. Summary of Previous Nordic Studies on Food Labelling........................................... 17

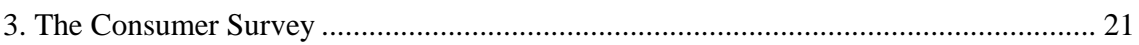

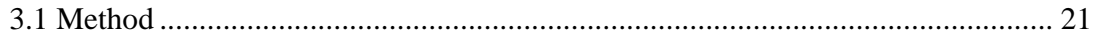

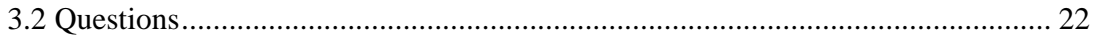

3.3 The Results of the Survey - Overhead presentation of Survey on Nordic Consumers Attitudes to Food Labelling ……....................................................... 23

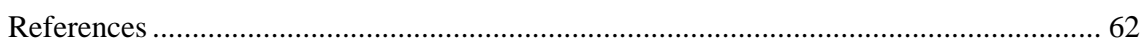

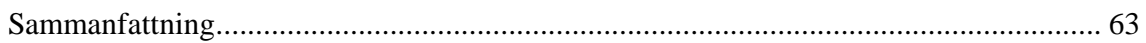





\section{Preface}

At the initiative of the National Food Administration in Sweden and the other Nordic countries, and with the support of the Nordic Council of Ministers, Synovate Temo in Sweden conducted a quantitative study on Nordic consumers' attitudes to food labelling.

The survey was carried out under the supervision of a project group of representatives from the National Food Safety Authorities in the Nordic countries:

- Anita Utheim Nesbakken, Norwegian Food Safety Authority

- Tytti Itkonen, Finnish Food Safety Authority, Evira, Finland

- Lars Aslo-Petersen, Danish Veterinary and Food Administration

- Sesselja María Sveinsdóttir /Jónína P. Stefánsdóttir, Environment and Food Agency of Iceland

- Birgitta Lund, National Food Administration, Sweden

- Svanhild Foldal, National Food Administration Sweden, project coordinator

Lena Hammers and David Ahlin at Synovate Temo in Sweden have conducted the analysis, and are responsible for the presentation of the results. Synovate's consultants are responsible for the conclusions and recommendations that are to be found in the analytical part of the report.

The project group is responsible for the conclusions and recommendations in this report.

Lena Janson from the National Food Administration Sweden has written the Summary of Previous Nordic Studies on Food Labelling.

Lena Janson, Lena Wallin and Ann Marie Svedin from the National Food Administration Sweden have contributed during the planning process. 



\section{Summary}

This report summarizes the final results of a quantitative study on Nordic consumers' attitudes to food labelling. The survey was conducted at the initiative of the Food Safety Authorities in the Nordic countries and with the support of the Nordic Council of Ministers.

The purpose of the study was to collect updated information and knowledge on the needs and attitudes of Nordic consumers regarding food labelling. The study aims to contribute with information, knowledge and facts in preparation for the upcoming European Union revision of the food labelling regulations.

Synovate Temo in Sweden conducted the survey under the supervision of a project group of representatives from the National Food Safety Authorities in the Nordic countries. The study was conducted in the five Nordic countries Sweden, Norway, Denmark, Finland and Iceland.

The questions have been written in cooperation between the project group of representatives from the National Food Safety Authorities in the Nordic countries and the Research Consultants from Synovate Temo in Sweden. Both open-ended questions and questions with fixed alternatives as answers have been put to Nordic consumers. The main subjects were:

- what information do consumers want to see on food labelling

- what is the relative importance of different items of information

- what is it that makes it easy for consumers to locate, read and understand information on food labels

- attitudes towards ideas on replacing compulsory consumer information, today printed on labels, with new types of pictures or symbols

- attitudes towards existing labelling regarding the origin of food products

- the need for information about the origin of the raw material in food products

- how should origin be labelled on food products

The interviews were conducted within the framework of a telephone omnibus survey with the general public in each country. More than 1,000 interviews were conducted in each country. A random sample was drawn from the general public 16 years and older. Interviews were conducted from 16-26 October 2006.

The preliminary results were presented at a Nordic seminar on food labelling, held 20-21 November 2006 in Norway (TemaNord 2006:601). 


\section{Summary of Findings}

It should be taken into consideration that the results of the survey to a certain extent give a snapshot of what consumers in the Nordic countries were preoccupied with at the time that the survey was carried out. If the survey had been carried out six months earlier or six months later, different answers could have been obtained for certain questions. In Denmark there has been a great deal of focus during the past year on several cases where there has been repackaging of old meat, in Sweden origin labelling has been discussed a great deal during the past year and in Norway there has been a sugar debate. The consumers' answers summarized below in several cases reflect the most topical questions in the media in each country.

According to the answers in this survey, information about ingredients, nutritional contents such as sugar, fat, salt and energy, "best before date", and country of origin must be printed clearly on the food package. This is the "top-of-mind" information Nordic consumers want to see on food labels to be able to make a conscious choice when buying food.

The "top-of-mind" answers in this survey show that consumers consider information on nutritional contents and country of origin, among other items, as important information. This is information that is at present not compulsory in food labelling. This result supports the current trend in consumer demands on food labelling information in order to be able to make an informed choice.

Furthermore it is very interesting that information about ingredients comes out on top when the consumers themselves prioritize in this openended question in spite of the fact that this has not been a topical question in the media.

Out of a list of nine various contents of information on food labels, information on "best before date" comes out on top in all Nordic countries (97\%). Information on ingredients (90\%), type of food product (89\%) and nutritional contents (83\%) are also considered very important or quite important by consumers in all Nordic countries. Even information on substances that can cause allergic reactions (79\%) and country of origin (78\%) are important issues.

Ethical information, e.g. regarding animal welfare and human rights, is important but least important (61\%) among the chosen subjects of information to consumers in order for them to be able to make a conscious choice.

The introduction of regulations relating to the minimum print size in order to facilitate legibility is a popular idea with consumers in all five Nordic countries (74\%). Nordic consumers also welcome the idea that compulsory labelling information is always laid out in the same format on all packages (74\%).

The introduction of regulations in order to facilitate compulsory labelling information always being printed in the same place on all packages 
and to limit the number of authorized languages on packages is significantly less important to Nordic consumers. In general, the survey shows that these questions are not so important to the younger age group and vice versa for the older age group. This is perhaps something to be considered bearing in mind the rapidly aging population of Europe.

Nordic consumers have an undecided or sceptical attitude towards the proposal to replace consumer information in text in food labelling with new types of pictures and symbols. $47 \%$ of Nordic consumers think it is a very good or quite good proposal, while $48 \%$ think it is not so good or not at all good. Especially consumers in Norway and Finland have a clearly negative attitude towards this proposal. Consumers in Sweden and Denmark are undecided. Iceland is the only country where consumers have a positive attitude to this idea. It should however be taken into account that this survey was done by telephone interviews. It is recommended that this question is further investigated in consumer focus groups where it would be possible to explain to the consumers what the symbols mean, what they would look like, show what kind of text would be replaced with symbols etc.

Regarding existing labelling of origin, this survey clearly shows that Nordic consumers are discontent with current labelling which does not inform about the origin of primary products. This is a uniform answer from all the Nordic countries: the majority of the consumers (73\%) think that it is not good or not at all good that you do not see what country the characterizing ingredient of the product come from.

Information on which country the primary products originate from concerning fresh meat (92\%), meat products such as smoked ham (88\%) and the meat in a sausage (86\%) is considered to be very important or quite important to know for Nordic consumers. It is also considered to be important to know from where the meat in a pizza (79\%) as well as fresh fruit and vegetables (79\%) originates. To have the information on where the primary products originate from in a processed product such as jam is also considered to be important, but not as important as when the products are fresh or raw.

The results from the open-ended question about how country of origin should be shown on food packages shows that consumers in general do not have a sophisticated opinion about which specific items of information they really require concerning origin. It is, however, clear that information about origin is very important to Nordic consumers although many consumers do not know the difference between different types of labelling regarding origin. A substantial proportion of consumers also comment on the need for clearly printed information that is easy to read. The answers in this survey clearly underpin the need to clarify the current definition as well as identify common criteria for the use of origin labelling. 



\section{Conclusions and Recommendations}

\section{Important labelling information}

The survey documents that a large majority of the just over 5, 000 consumers who participated in the survey consider that it is particularly important that there is information about food's

- ingredients (list of ingredients)

- nutritional contents (sugar, fat, salt, energy etc)

- shelf life (best-before-date) and

- origin labelling (country of origin)

on the package in order to be able to make a conscious choice.

It should be noted that this kind of survey can to a certain extent reflect current debate in the media. However, one of the most important conclusions from this survey is that Nordic consumers appreciate and wish to keep the complete list of ingredients that is to be found on food packages today. There is reason to particularly emphasize this as it has not been a topical question in the media recently.

It should also be noted that Nordic consumers wish to have information about food's nutritional contents and origin and that such information should be on the package. This is in line with results from previous consumer surveys, which showed, amongst other things, that Nordic consumers consider that information on nutritional contents and the country of origin should be obligatory for all food (TemaNord 2001:573 and TemaNord 2002:589). At present information on nutritional contents and origin are not as a general rule obligatory in label-ling information.

In connection with the review of EU labelling regulations, origin labelling has been emphasized as an important question both by the Nordic countries and most of the EU's member states. Today there is no definition of origin/country of origin and use of the expression can thus often be misleading for consumers. There is therefore a need to introduce a definition of origin/country of origin and other expressions for origin, such as manufactured, packaged, statement of origin of raw materials etc and to determine common criteria for the application of different expressions for origin, so that the consumers are not misled. This work should precede the review of EU labelling rules. 


\section{Clear and easily understood labelling (legibility)}

The survey shows that Nordic consumers want to have clear labelling that is legible and easy to understand. A majority of Nordic consumers welcome measures to facilitate for consumers to be able to take in information and increase the legibility of food packages. There is strong support for the introduction of a minimum print size and for obligatory labelling information always being laid out in the same format on the package.

This is a proposal which also has the support of the food industry and the food trade (TemaNord 2006: 601) and which will be discussed in connection with the review of EU labelling rules. Concrete examples could be produced here, or guidance could be drawn up for how this could be implemented in practice. Examples or guidance should be drawn up in dialogue with representatives for consumer organizations, the food industry and the food trade and with the support of professional graphic designers.

One conceivable way of simplifying the labelling of food packages is to replace text with various symbols and pictures. This has been discussed in connection with the review of EU labelling rules and elsewhere. The survey shows that Nordic consumers are doubtful or even sceptical about replacing the text on labels with new symbols or pictures. If in connection with the review of EU labelling rules the need should arise to replace existing text, e.g. information about ingredients or allergenic substances, with symbols or pictures it should be further investigated how consumers perceive the use of different symbols and pictures in food labelling in order to avoid the risk of misleading labelling. This is especially important with regard to allergenic ingredients, where a misunderstanding can be fatal. 


\section{Introduction}

The Nordic countries have a long history of working together on food labelling. This cooperation, which has been formalized under the Nordic Council of Ministers and the Committee of Senior Officials for Food Issues, has led to a number of important projects and surveys being carried out since the 1990s.

In the area of labelling a common view and common positions have been developed over the years on the basis of a common set of basic Nordic values. The consumer perspective is important when the drawing up of new labelling regulations is to be discussed. Nordic proposals and standpoints in the area of labelling have had an impact in international forums, e.g. in the EU and Codex Alimentarius. Allergy labelling, demands for a complete list of ingredients etc. are examples of this.

Food labelling in the Nordic countries conforms to EU legislation. The European Commission has started a review of the labelling legislation to make it simpler and more up-to-date. A proposal for revised EU labelling legislation will be brought up at the end of 2007.

At the initiative of the National Food Administration in Sweden and the other Nordic Food Control Authorities, and with the support of the Nordic Council of Ministers, Synovate Temo in Sweden has conducted a quantitative study on Nordic consumers' attitudes to food labelling. The purpose of the study was to collect updated information and knowledge on the needs and attitudes of Nordic consumers regarding food labelling. The study aims to contribute with information, knowledge and facts in preparation for the upcoming European Union revision of the food labelling rules. 



\section{Summary of Previous Nordic Studies on Food Labelling}

Food labelling has been a topic of great importance for the Nordic countries. Under the Nordic Council of Ministers and the Committee of Senior Officials for Food Issues several projects have been carried out since the early 1990s. A study dated 1994 started to give an overview of food labelling in the Nordic countries. This study showed that there were gaps in existing knowledge about what consumers want, need and understand about labelling (Food Labelling TemaNord 1998:577). To fill the gaps the Nordic Council of Ministers started extensive work on food labelling. This summarizes some of the Nordic studies carried out in recent years.

A pan-Nordic consumer survey was carried out in 2000 and resulted in the report Food Labelling: Nordic Consumers' Proposals for Improvements (TemaNord 2001:573). The pan-Nordic survey showed that it was the wish of consumers that:

- Country of origin should be mandatory (86\%).

- Date of production should be mandatory - not just shelf life (81\%).

- Nutritional declaration should be mandatory (79\%).

- List of ingredients should state each and every ingredient in percentage of total products (58\%).

- Inspection and supervision: the authorities should make strict rules and carry out thorough supervision of the use of additives and preservation (86\%).

- Health information: the authorities and experts should inform consumers which foods are "healthy" and nutritionally appropriate (63\%).

- The study mentioned above resulted in the report Nordic Policy towards the Labelling of Foods (TemaNord 2002:589). The following recommendations for the Nordic initiatives stated that:

- Foods should have their country of origin marked ("origin" needs to be defined).

- Foods ought to be labelled with both use by dates \& production or initiation dates to give consumers a chance to judge a product's freshness and other qualities relating to the product's age.

- Nutritional declarations should be mandatory on all pre-packed foods.

- List of ingredients should be complete and include all ingredients. The presence of known ingredients should be stated without exception. The amount of significant ingredients should be stated including ingredients present in significant quantities/ingredients consumers 
associate with the food/ingredients emphasized in labelling/on the packaging.

- Foods and ingredients which contain or consist of genetically modified organisms (GMOs) or are produced using GMOs should be labelled.

- If health claims labelling of foods is to be allowed, claims should be documented by health science and the consumption of the food in question should have clear health benefits.

- Ethical \& environmental values in food production ought to be credited, and how consumers could best be informed of these values needs to be clarified.

- The communication of risk with the use of additives should be improved.

- Simple and accessible models for labelling need to be developed (advantages \& possible disadvantages of standardized presentation of labelling information ought to be researched).

- Experimentation with electronic product labelling should be initiated in shops and on the Internet in cooperation with the food industry, the food trade, public officials and interest organizations.

Following these results a new project group was formed in 2001 to deal with nutrition labelling. Nutrition labelling is an important tool of public health policy. However, indication of nutritional value of a product is optional, unless a nutrition claim is used. The literature review and the formats developed to meet consumer needs were presented in the report Proposals for New Nutrition Labelling Formats (TemaNord 2002:554).

The project group was also responsible for carrying out consumer tests, the aim of which was to formulate recommendations to the Nordic Council of Ministers and possibly a common Nordic Policy on nutrition labelling. A nutrition label is a tool for delivering information and should be supported by educational and other efforts. Nutrition Labelling: Nordic Recommendations Based on Consumer Opinions (TemaNord 2004:508):

- Nutrition labelling should be mandatory on all pre-packed foods.

- There is generally small understanding of nutrition labelling. Nutrition labels should be standardized and the text should be legible.

- Nutrition information should consist of the following mandatory list: energy, fat (of which hard fat), carbohydrates (of which sugars), fibre, protein, salt.

- The formats should be mandatory and should give information per 100 g, per portion and a simple guidance system should be tested (the term $\mathrm{RDI}$ is too complicated). 
Consumers must also be guaranteed the possibility of choosing foods on the basis of ethical values. These experiences are described in the report Ethical labelling of foods (ANP 2004:741). The information is often given in text or by a symbol. The initiative for ethical labelling has often been taken by NGOs in order to promote objectives such as sustainable production and fair trade. Existing labelling schemes should be maintained and strengthened within the existing framework. There could be considerable difficulties in introducing a general sustainability label, especially for industrial composite foods. The project group laid down some concrete proposals for joint Nordic initiatives to promote consumer information on ethical conditions in food production:

- Development of information and educational methods concerning ethics in food

- Analysis of socio-economic consequences of the use of different methods of informing about ethical conditions in food production.

- Nordic guidelines for the use of ethical claims in marketing

- Labelling of fish from sustainable fisheries

- Nordic database on sustainable production

- Methods for assessing the environmental impact of food.

- Development of criteria and labelling for animal welfare in cooperation with the food industry.

In accordance with this work a seminar with workshops was also held which is summarized in the report Seminar - Ethical information about Food (TemaNord 2004:545). 



\section{The Consumer Survey}

\subsection{Method}

The survey was carried out by means of telephone interviews in all five Nordic countries. The interviews were carried out within the framework of so-called omnibus surveys with the general public in each country.

Just over 1,000 interviews were carried out in each country with a random, representative sample of the general public 16 years of age and older. A total of just over 5,000 telephone interviews were carried out for the survey. The interviews were carried out during the period 16-26 October 2006.

\section{Omnibus survey}

Synovate Temo Direkt is a regularly recurring telephone omnibus among the Swedish general public. "Omnibus" means that the questionnaire is shared by different clients. The survey is carried out in an identical way on each occasion. This enables comparisons over time. Synovate Temo in Sweden checks that questions from different clients, but which deal with similar areas, are not included in the same questionnaire.

The survey is carried out as a daily omnibus with a separate sample. Each day 250 interviews are carried out. Similar methods were used in the other Nordic countries.

\section{Sample}

The sample is representative of the general public in the Nordic countries, 16 years of age and older. A new sample is drawn for each questionnaire. The sample is drawn using the Synovate Temo in Sweden model for telephone-number-based population samples. In each household the interviewee is randomly chosen by means of a question about who was the last person in the household to have a birthday. Similar methods were used in the other Nordic countries.

\section{Form of contact}

Telephone interviews, home telephone numbers.

\section{Field work}

The interviews are carried out from Synovate Temo's telephone centres by trained interviewers. The interviews are carried out during afternoons and evenings. Similar methods were used in the other Nordic countries. 


\section{Weighting}

Collected data are post-stratified. As the sample is household-based, oneperson households, for example, could be over-represented in the collected material without this weighting. The weighting is done simultaneously for all the four variables of sex, age, household size and place of residence.

\section{Recording of data}

The results are recorded as vertical percentages using "chi square", where the percentage figures from the top down column-wise add up to $100 \%$ or more. Plus and minus signs indicate which values significantly deviate from the corresponding values in the total column. Plus (+) indicates that the value is significantly higher, minus (-) that the value is significantly lower.

\section{Reliability}

The table below records the margin of error for measured percent-ages with different random sample sizes. The true percentage is with a probability of $95 \%$ within the interval $+/-$ the number of percentage points stated in the table.

\begin{tabular}{rcccccccccccc}
\hline Sample size & \multicolumn{2}{c}{ Error size when the answers are distributed as follows: } & & & & \\
(= base figure) & $\mathbf{5 - 9 5 \%}$ & $\mathbf{1 0 - 9 0 \%}$ & $\mathbf{1 5 - 8 5 \%}$ & $\mathbf{2 0 - 8 0 \%}$ & $\mathbf{2 5 - 7 5 \%}$ & $\mathbf{3 0 - 7 0 \%}$ & $\mathbf{3 5 - 6 5 \%}$ & $\mathbf{4 0 - 6 0 \%}$ & $\mathbf{4 5 - 5 5 \%}$ & $\mathbf{5 0 - 5 0 \%}$ \\
\hline 30 interviews & \pm 8.0 & \pm 10.0 & \pm 13.0 & \pm 14.6 & \pm 15.8 & \pm 16.7 & \pm 17.4 & \pm 17.9 & \pm 18.2 & \pm 18.3 \\
50 interviews & 6.2 & 8.5 & 10.1 & 11.3 & 12.2 & 13.0 & 13.5 & 13.9 & 14.0 & 14.1 \\
74 interviews & 5.0 & 6.9 & 8.2 & 9.2 & 10.0 & 10.6 & 11.0 & 11.3 & 11.5 & 11.5 \\
100 interviews & 4.4 & 6.0 & 7.1 & 8.0 & 8.7 & 9.2 & 9.5 & 9.8 & 9.9 & 10.0 \\
200 interviews & 3.1 & 4.2 & 5.1 & 5.6 & 6.1 & 6.5 & 6.8 & 6.9 & 7.0 & 7.1 \\
250 interviews & 2.8 & 3.8 & 4.5 & 5.1 & 5.5 & $\mathbf{5 . 8}$ & 6.0 & 6.2 & 6.3 & 6.3 \\
400 interviews & 2.2 & 3.0 & 3.6 & 4.0 & 4.3 & 4.6 & 4.8 & 4.9 & 5.0 & 5.0 \\
500 i interviews & 2.0 & 2.7 & 3.2 & 3.6 & 3.9 & 4.1 & 4.3 & 4.4 & 4.5 & 4.5 \\
1000 interviews & 1.4 & 1.9 & 2.3 & 2.5 & 2.7 & 2.9 & 3.0 & 3.1 & 3.1 & 3.2 \\
\hline
\end{tabular}

If for example 69\% have answered "YES" to a question and 250 people have answered this question, the margin of error is $5.8 \%$. We can then with a probability of $95 \%$ say that this true value is between 63.2 and $74.8 \%$.

\subsection{Questions}

The survey questions have been written in cooperation between the project group of representatives from the National Food Safety Authorities in 
the Nordic countries and the Research Consultants from Synovate Temo in Sweden. The consultants have above all contributed by formulating questions that it is possible to ask the general public in telephone interviews. Both open-ended questions and questions with fixed alternatives as answers have been put to Nordic consumers. The main subjects in the survey were:

- what information do consumers want to see on food labelling

- what is the relative importance of different items of information

- what is it that makes it easy for consumers to locate, read and understand information on food labels

- attitudes towards ideas on replacing compulsory consumer information, today printed on labels, with new types of pictures or symbols

- attitudes towards existing labelling regarding the origin of food products

- the need for information about the origin of the raw material in food products

- how should origin be labelled on food products

\subsection{The Results of the Survey}

Overhead presentation of Survey on Nordic Consumers Attitudes to Food Labelling (Synovate Temo 2006)

Lena Hammers and David Ahlin at Synovate Temo in Sweden have conducted the analysis, and are responsible for the presentation of the results. 


\section{Nordic consumer survey on Food Labelling}

- Consumer Survey in Sweden, Norway, Denmark, Finland and Iceland

First report /Nordic countries

T-113099

Nordic Council of Ministers

Synovate:

Date:

David Ahlin, Lena Hammers 2006-12-05

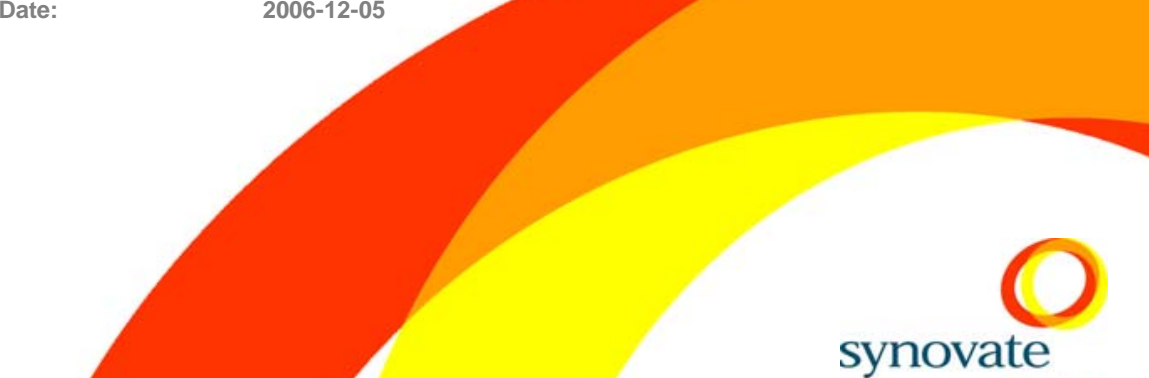

Temo

\section{Contenst}
O Background of survey
O Method and process
O Subjects and questions

\section{Results*}

O What information is most important to the Nordic consumer?

$O$ What is important in order to locate, read and understand food label information?

O Attitudes towards existing food labelling

$O$ Labelling of origin

O Summary 


\section{Background to study on Nordic consumers}

O At the initiative of the National Food Administration in Sweden and the other Nordic countries and the Nordic Council of Ministers, Synovate Temo has conducted a quantitative study on Nordic consumers' attitudes to food labelling. The study was conducted in the five Nordic countries Sweden, Norway, Denmark, Finland and Iceland.

O The survey was carried out under the supervision of a group of representatives from the National Food Administrations in the Nordic countries.

The purpose of the study is to collect updated information and knowledge on the needs and attitudes of Nordic consumers regarding food labelling.

The study aims to contribute with information, knowledge and facts in preparation for the upcoming European Union revision of the food labelling regulations.

\section{Method and process}

O The survey was conducted by telephone interviews in the five Nordic countries.

O The interviews were conducted within the framework of an omnibus survey with the general public in each country.

O More than 1,000 interviews were conducted in each country. A random sample was drawn from the general public 16 years and older.

O Interviews were conducted from October 16 to October 26, 2006. 


\section{Subjects and questions}

$O$ The questions have been written in cooperation with the National Food Administrations in the Nordic countries and the Research Consultants from Synovate. Both open-ended questions and questions with fixed alternatives as answers have been put to Nordic consumers.

O Subjects:

- what information do consumers want to see on food labelling

- what is the relative importance of different types of information

- what is it that makes it easy for consumers to locate, read and understand information on food labels

- attitudes towards ideas on replacing compulsory consumer information, today printed on labels, with new types of pictures or symbols

- attitudes towards existing labelling regarding the origin of food products

- the need for information about the origin of the raw material in food products

- how should origin be labelled on food products

\section{Question 1}

Here are a number of questions relating to food, packaging, and information printed on food packaging.

To be able to make a conscious choice when you buy food, what information do you consider must be printed on the package? 


\section{What information must be printed on the food package? Top-of-mind - Sweden}

1. Ingredients, contents

"Ingredienser är viktigt eftersom jag är diabetiker. Jag är även synskadad och behöver hjälp av

andra.

"Innehållsdeklarationen, så att man vet vad man får i sig när man använder produkten."

2. Country of origin

"Det är viktigt med ursprungslandet, varifrån varorna kommer."

"Kött ska ha ursprungsland."

3. Best-before-date "Datum när det går ut så man vet hur färskt det

4. Content of sugar, fat etc

"Jag tittar gärna på socker, fetthalt och sånt som ingằ $\mathrm{i}$ varan.

"Vad det innehåller, så jag vet vad jag får i mig nåt som man vet med sig är skadligt."

5. Price, price per kilo

"Priset är intressant och även pris per

"Pg."
6. Ethical information

7. That it is a Swedish product

8. Weight
What information must be printed on the food package?

\section{What information must be printed on the food package? Top-of-mind - Norway}

1. Ingredients, contents

"Hva det er, hva det inneholder.

6. Ethical information

"Hva slags ingredienser, allergideklarasjon."

2. Best-before-date

"Når den går ut på dato.

"Når det är produsert og holdbarhetsdato.

7. Manufacturer

Content of sugar, fat etc

"Om det er tillsatt mye fett og sukker."

"Sukker og fett innhold, andel mettet og umettet fett."

4. Country of origin

"Hvor produktet er produsert.

What information must

be printed on the food package?

5. Price, price per kilo

"Hva varen koster." 


\section{What information must be printed on the food package? Top-of-mind - Denmark}

1. Best-before-date

"Hvor gammelt det er."

6. Ethical information

"Salgsdato og produktionsdato."

2. Content of sugar, salt, fat etc

"Energi og fedtstof og kulhydrater,

tilsætningsstoffer, fedttype."

7. Manufacturer/ brand

"Indhold samt næringsindhold"

8. Price, price per kilo

3. Ingredients, contents

"Indhold, hvad det er man købe."

What information must

"Indholds deklaration, økologi."

be printed on the food package?

\section{Country of origin}

"Hvor det oprindeligt kommer fra."

"Hvilket land det kommer fra."

5. Information about contents that could cause

allergic reactions

"At der står hvad der er i, proteiner, skadestoffer,

usundhed."

"Mængden af farve- og tilsætningsstoffer"

\section{What information must be printed on the food package? Top-of-mind - Finland}

1. Ingredients, contents "One must know the list of ingredients."

"List of ingredients real detailed."

2. Content of sugar, fat, salt et cetera

"Contents, amount of fat, calories."

"Calories and fat and how long it is preserved."

3. Best-before-date

"Best-before-date, and date when the product was manufactured."

4. Country of origin

"That depends on the product. If it's meat then I would like to know from what country it came. "Country of origin, that is the most important

5. Price, price per kilo

"Price and
weight."

"To see good quality and the price"
6. That it is a Finnish product

7. Ethical information

8. Weight

What information must be printed on the food package? 
What information must be printed on the food package? Top-of-mind - Iceland

1. Ingredients, contents

"Correct ingredient listing about everything that is in it."

6. Ethical information

"Precise listing of ingredients like additives and weighing ingredients."

7. Manufacturer

2. Best-before-date " Depends if it is fresh or not, date of production and last day to be sold.

" First and foremost sell before date and

3. Content of sugar, fat, salt etc "Calories, nutritional values, sugars, fats, "How much fat, sugar, calories and vitamins there are."

8. Weight

Price, price per kilo

"I buy a lot for companies, it matters to see the price clearly."

5. Country of origin

" From what country they are."

What information must be printed on the food package?

Summary - top-of-mind - to make a conscious choice What information must be printed on the package?

\section{Ingredients, contents}

"One must know the list of ingredients."

"List of ingredients really detailed."

Content of sugar, fat, salt et cetera

"Contents, amount of fat, calories."

"Calories and fat and how long it preserves."

\section{Best-before-date}

"Best-before-date, and date when the product was manufactured."

Country of origin

" From what country they are." 


\section{Question 2}

I will now read out various items of information which can be found on food packaging. How important is it to you that the following information is stated on the package for you to be able to make a conscious choice about a certain kind of food?

Is it very important, quite important, not so important or not at all important?"

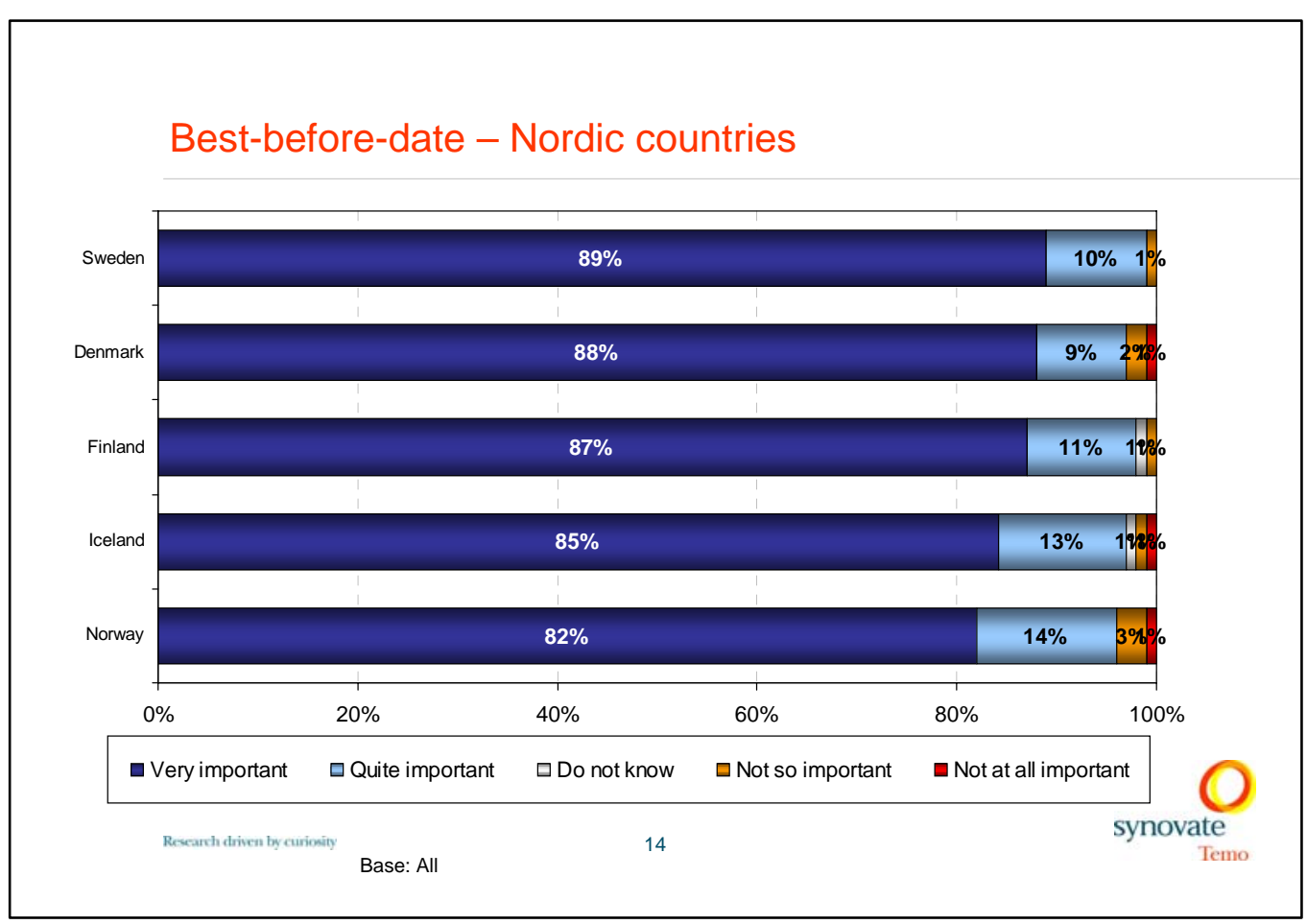




\section{Best-before-date - Nordic countries}

O There are no significant differences in Sweden.

O Students find the issue significantly less important in Denmark - $81 \%$ compared with $88 \%$ totally.

$O$ There are no significant differences in Finland.

0 Men and $60+$ find the issue significantly less important in Iceland $-81 \%$ and $78 \%$ compared with $85 \%$ totally. Women and 30-44 years of age find the issue significantly more important - $88 \%$ and $90 \%$ compared with $85 \%$ totally.

$060+$ find the issue significantly less important in Norway $74 \%$ compared with $82 \%$ totally. $30-44$ years of age and people living in Oslo find the issue significantly more important $-87 \%$ and $89 \%$ compared with $82 \%$ totally.

The type of food product - Nordic countries

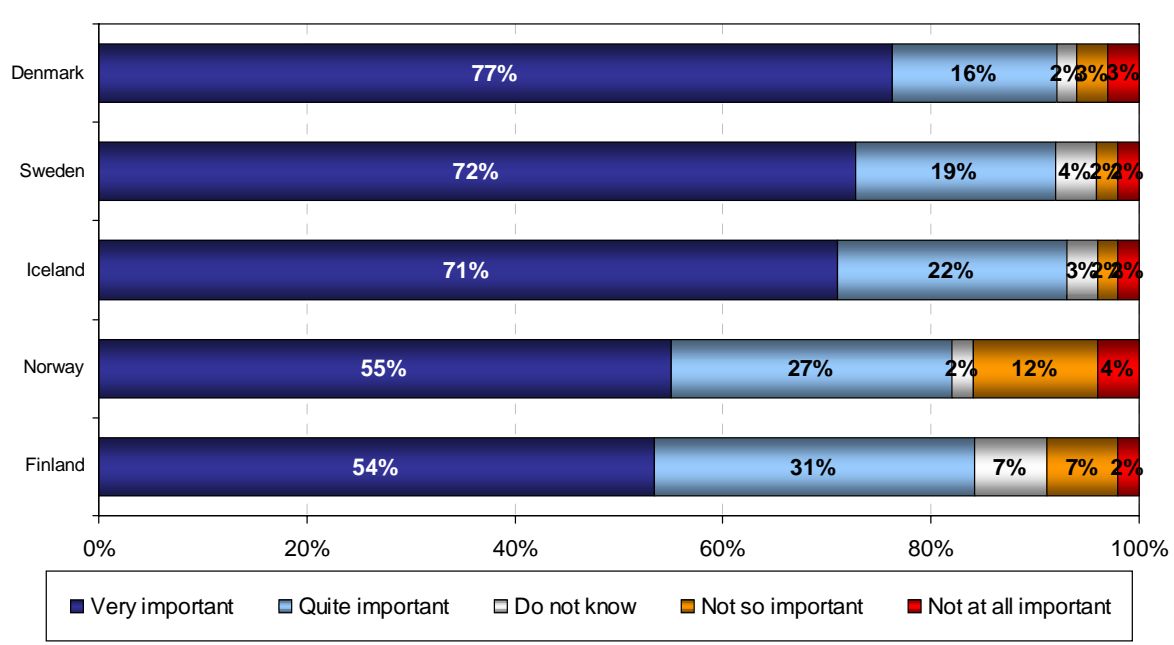




\section{The type of food product - Nordic countries}

O There are no significant differences in Denmark.

O Men find the issue significantly less important in Sweden - $63 \%$ compared with $72 \%$ totally. Women find the issue significantly more important - $81 \%$ compared with $72 \%$ totally.

O Men find the issue significantly less important in Iceland - $62 \%$ compared with $71 \%$ totally. Women find the issue significantly more important - $80 \%$ compared with $71 \%$ totally.

O Men find the issue significantly less important in Norway - $50 \%$ compared with $55 \%$ totally. Women find the issue significantly more important - $60 \%$ compared with $55 \%$ totally.

0 There are no significant differences in Finland.

Information on substances which can cause allergic reactions Nordic countries

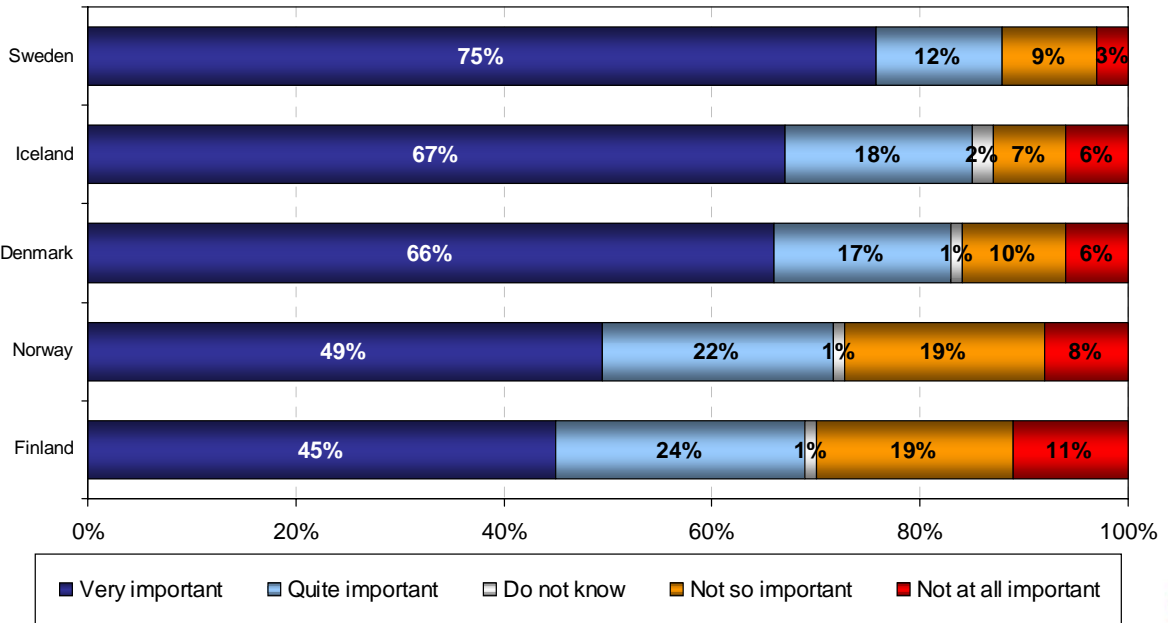




\section{Information on substances which can cause allergic reactions - Nordic countries}

O Men find the issue significantly less important in Sweden - $71 \%$ compared with $75 \%$ totally. Women find the issue significantly more important - $79 \%$ compared with $75 \%$ totally.

O Men find the issue significantly less important in Iceland - $57 \%$ compared with $67 \%$ totally. Women find the issue significantly more important - $77 \%$ compared with $67 \%$ totally.

O Men find the issue significantly less important in Denmark - $61 \%$ compared with $66 \%$ totally. Women find the issue significantly more important - $70 \%$ compared with $60 \%$ totally.

0 There are no significant differences in Norway.

O Men find the issue significantly less important in Finland - $37 \%$ compared with $45 \%$ totally. Women find the issue significantly more important - $53 \%$ compared with $45 \%$ totally.

The list of ingredients - Nordic countries

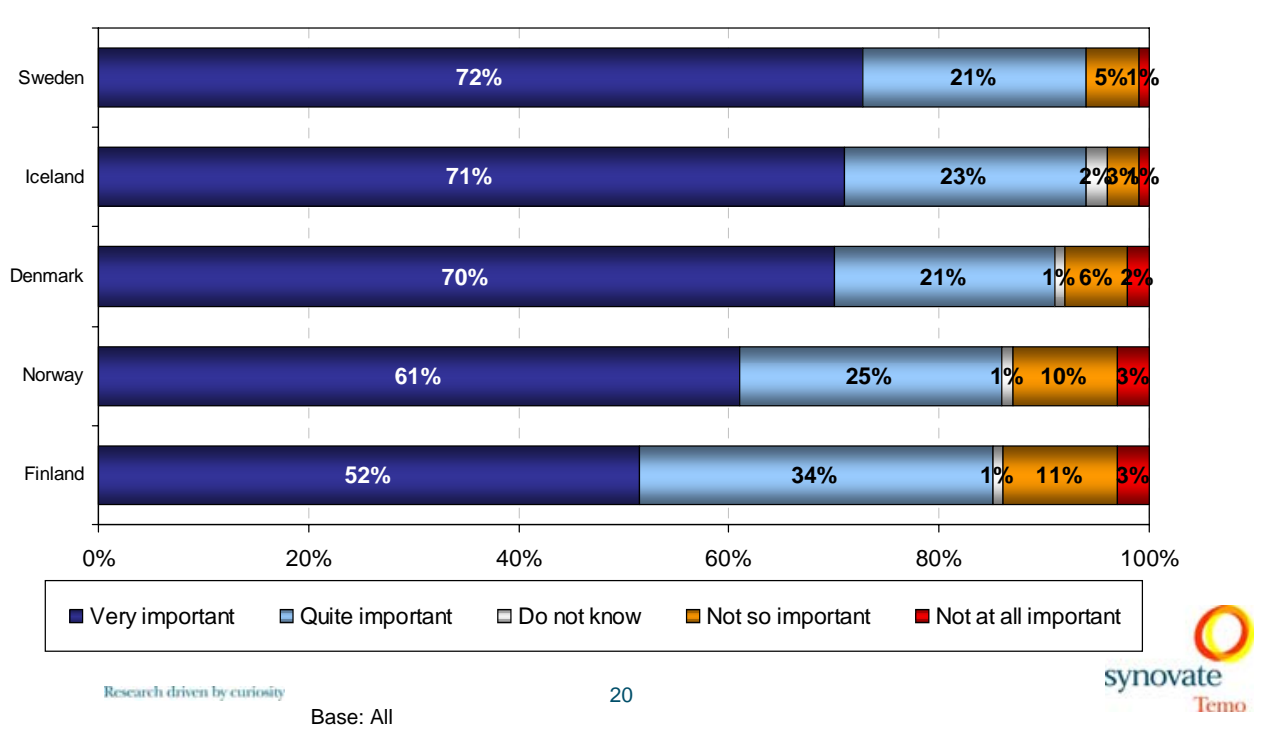


The list of ingredients - Nordic countries

O Men find the issue significantly less important in Sweden - $63 \%$ compared with $72 \%$ totally. Women find the issue significantly more important $-81 \%$ compared with $72 \%$ totally.

O Men find the issue significantly less important in Iceland - $63 \%$ compared with $71 \%$ totally. Women find the issue significantly more important $-79 \%$ compared with $71 \%$ totally.

O Men find the issue significantly less important in Denmark - $64 \%$ compared with $70 \%$ totally. Women find the issue significantly more important $-76 \%$ compared with $70 \%$ totally.

O Men find the issue significantly less important in Norway - $51 \%$ compared with $61 \%$ totally. Women find the issue significantly more important $-70 \%$ compared with $61 \%$ totally.

O Men find the issue significantly less important in Finland - $45 \%$ compared with $52 \%$ totally. Women find the issue significantly more important $-60 \%$ compared with $52 \%$ totally.

\section{Information on country of origin - Nordic countries}

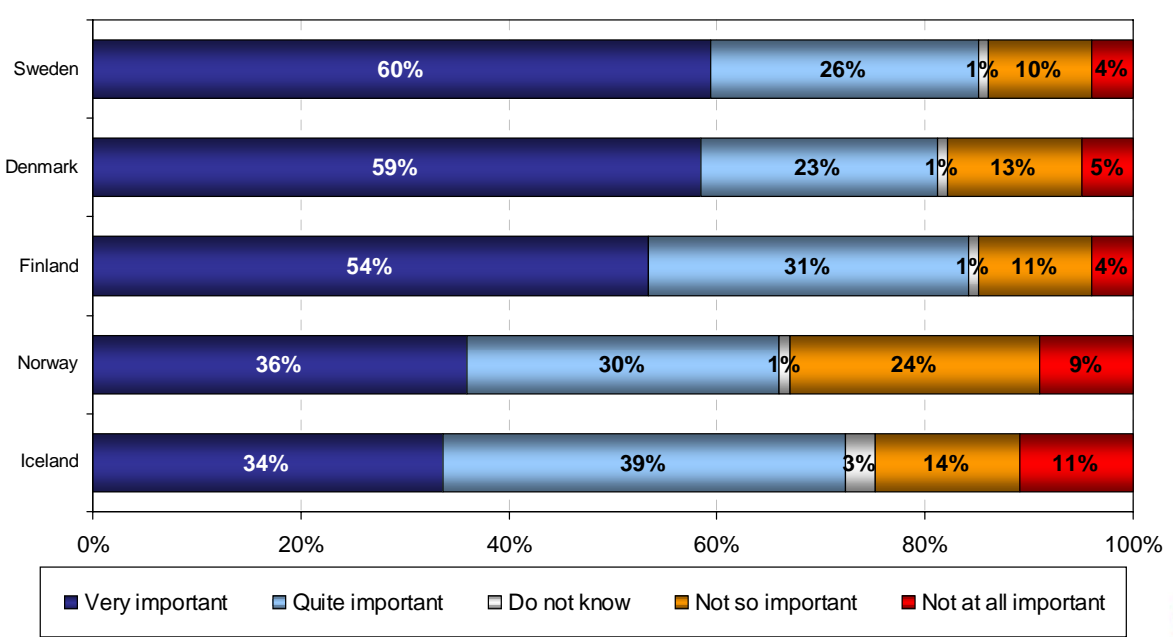




\section{Information on country of origin - Nordic countries}

O Men find the issue significantly less important in Sweden - $55 \%$ compared with $60 \%$ totally. Women find the issue significantly more important $-65 \%$ compared with $60 \%$ totally.

$O$ Men and 16-29 years of age find the issue significantly less important in Denmark - $52 \%$ and $43 \%$ compared with $59 \%$ totally. Women and 45-59 and $60+$ years of age find the issue significantly more important $-65 \%$, $66 \%$ and $66 \%$ compared with $59 \%$ totally.

$O$ Men and 16-29 years of age find the issue significantly less important in Finland $-49 \%$ and $44 \%$ compared with $54 \%$ totally. Women find the issue significantly more important - $58 \%$ compared with $54 \%$ totally.

O 16-29 years of age find the issue significantly less important in Norway $28 \%$ compared with $36 \%$ totally. 60 + years of age find the issue significantly more important $-45 \%$ compared with $36 \%$ totally.

O 16-29 years of age find the issue significantly less important in Iceland $16 \%$ compared with $34 \%$ totally. $45-59$ and $69+$ years of age find the issue significantly more important $-43 \%$ and $55 \%$ compared with $34 \%$ totally.

\section{Nutritional contents, e.g. calories, sugar, fat and salt -}

\section{Nordic countries}

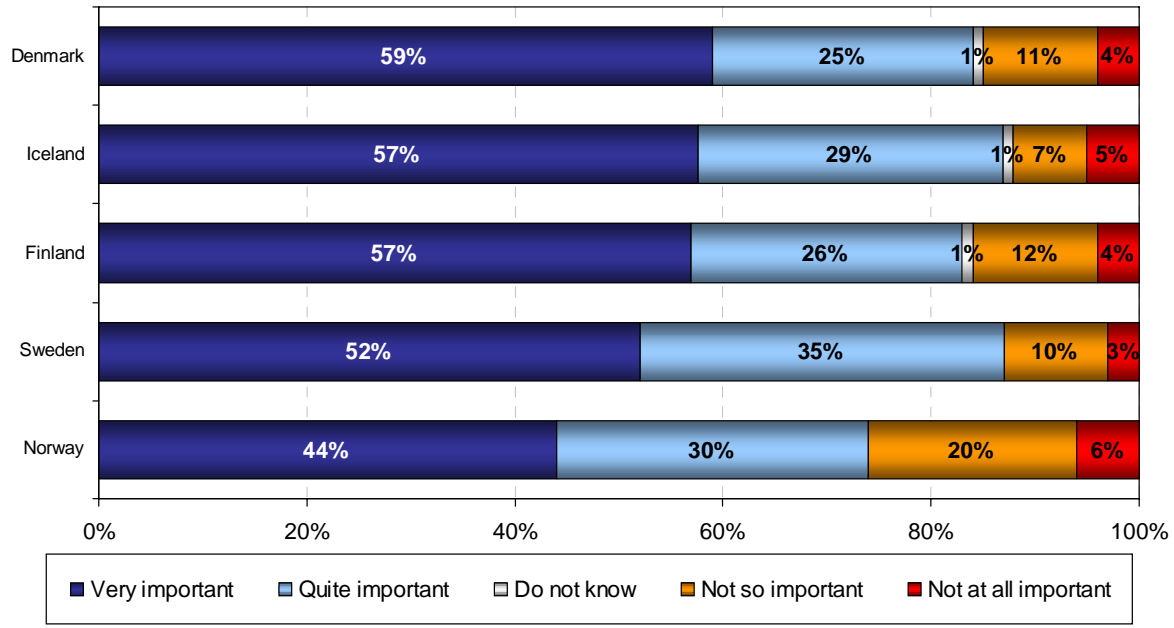

Research driven by curionit?

24 


\section{Nutritional contents, e.g. calories, sugar, fat and} salt - Nordic countries

O Men find the issue significantly less important in Denmark- $50 \%$ compared with $59 \%$ totally. Women and $45-59$ and $60+$ years of age find the issue significantly more important $-67 \%, 68 \%$ and $52 \%$ compared with $59 \%$ totally.

O Men and 16-29 years of age find the issue significantly less important in Iceland $-47 \%$ and $47 \%$ compared with $57 \%$ totally. Women find the issue significantly more important - $68 \%$ compared with $57 \%$ totally.

$O$ Men and 30-44 years of age find the issue significantly less important in Finland $-49 \%$ and $46 \%$ compared with $57 \%$ totally. Women and 60+ years of age find the issue significantly more important - $64 \%$ and $68 \%$ compared with $57 \%$ totally.

O Men find the issue significantly less important in Sweden - $45 \%$ compared with $52 \%$ totally. Women find the issue significantly more important $-58 \%$ compared with $45 \%$ totally.

O Men and 16-29 years of age find the issue significantly less important in Norway $-35 \%$ and $36 \%$ compared with $44 \%$ totally. Women and $60+$ years of age find the issue significantly more important $-51 \%$ and $50 \%$ compared with $44 \%$ totally.

\section{Ethical information, for example regarding environment, animal welfare and human rights - Nordic countries}

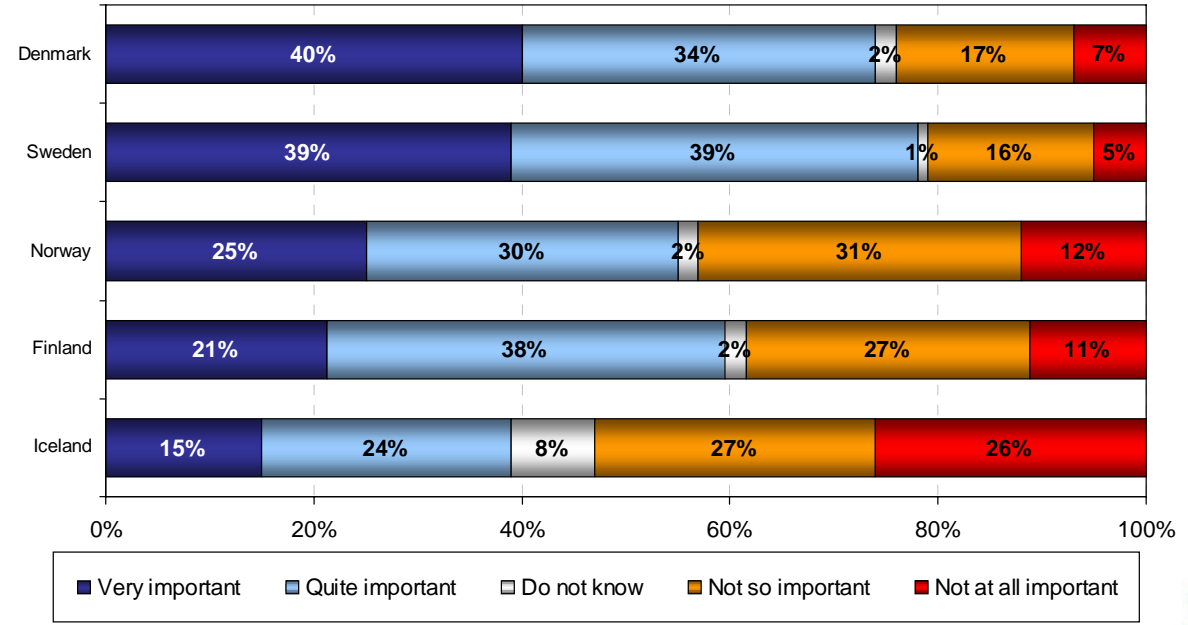




\section{Ethical information, for example regarding environment, animal welfare and human rights - Nordic countries}

Men and 30-44 years of age find the issue significantly less important in Denmark - $33 \%$ and $34 \%$ compared with $40 \%$ totally. Women and $45-59$ years of age find the issue significantly more important - $46 \%$ and $46 \%$ compared with $40 \%$ totally.

O Men find the issue significantly less important in Sweden - $33 \%$ compared with $38 \%$ totally. Women find the issue significantly more important - $45 \%$ compared with $39 \%$ totally.

O Men find the issue significantly less important in Norway - $21 \%$ compared with $25 \%$ totally. Women find the issue significantly more important - $29 \%$ compared with $25 \%$ totally.

O Men find the issue significantly less important in Finland - $14 \%$ compared with $21 \%$ totally. Women find the issue significantly more important - $28 \%$ compared with $21 \%$ totally.

O Men find the issue significantly less important in Iceland- $11 \%$ compared with $15 \%$ totally. Women find the issue significantly more important - $18 \%$ compared with $15 \%$ totally.

The proportion of characterizing ingredients, e.g. the proportion of raspberries in raspberry yogurt - Nordic countries

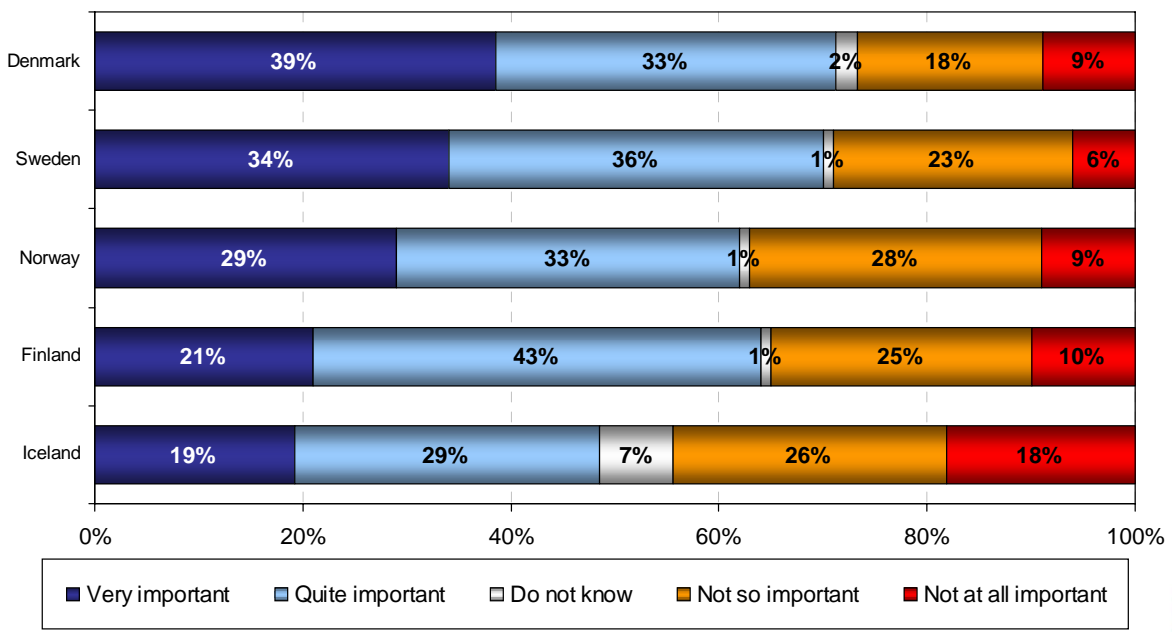


The proportion of characterizing ingredients, e.g. the proportion of raspberries in raspberry yogurt - Nordic countries

O Men find the issue significantly less important in Denmark - $32 \%$ compared with $39 \%$ totally. Women find the issue significantly more important $-45 \%$ compared with $39 \%$ totally.

O 16-29 years of age find the issue significantly less important in Sweden $26 \%$ compared with $34 \%$ totally. 60 + years of age find the issue significantly more important $-40 \%$ compared with $34 \%$ totally.

O 16-29 years of age find the issue significantly less important in Norway $19 \%$ compared with $29 \%$ totally. 60 + years of age find the issue significantly more important - $36 \%$ compared with $29 \%$ totally.

O 16-29 years of age find the issue significantly less important in Finland $16 \%$ compared with $21 \%$ totally. $45-59$ years of age find the issue significantly more important $-26 \%$ compared with $21 \%$ totally.

$O$ Men and 16-29 years of age find the issue significantly less important in Iceland- $14 \%$ and $11 \%$ compared with $19 \%$ totally. Women and 45-59 years of age find the issue significantly more important $-23 \%$ and $25 \%$ compared with $19 \%$ totally.

\section{What information is important to be able to make a conscious choice of food?}

O "Best-before-date" is the most important information in all the Nordic countries.

O Ethical information is important but least important among the chosen subjects of information to consumers in order to be able to make a conscious choice.

O Information on substances that can cause allergic reactions, ingredients and type of food is also considered important by consumers in all the Nordic countries.

O Information about nutritional contents is more important to consumers in Finland. Consumers in Finland also feel that information on country of origin is more important.

O Information on country of origin is less important to consumers in Norway and Iceland.

O Nutritional contents, substances that can cause allergic reactions and ethical information are generally more important to women. 


\section{Question 3}

How important are the following for you to be able to access the information on food packaging?

Would you say that it is...?

-The introduction of regulations relating to the minimum print size in order to facilitate legibility

- That compulsory labelling information is always laid out in the same format on all packages

- That compulsory labelling information is always printed in the same place on all packages

- Limiting the number of authorized languages on packages

The introduction of regulations relating to the minimum print size in order to facilitate legibility

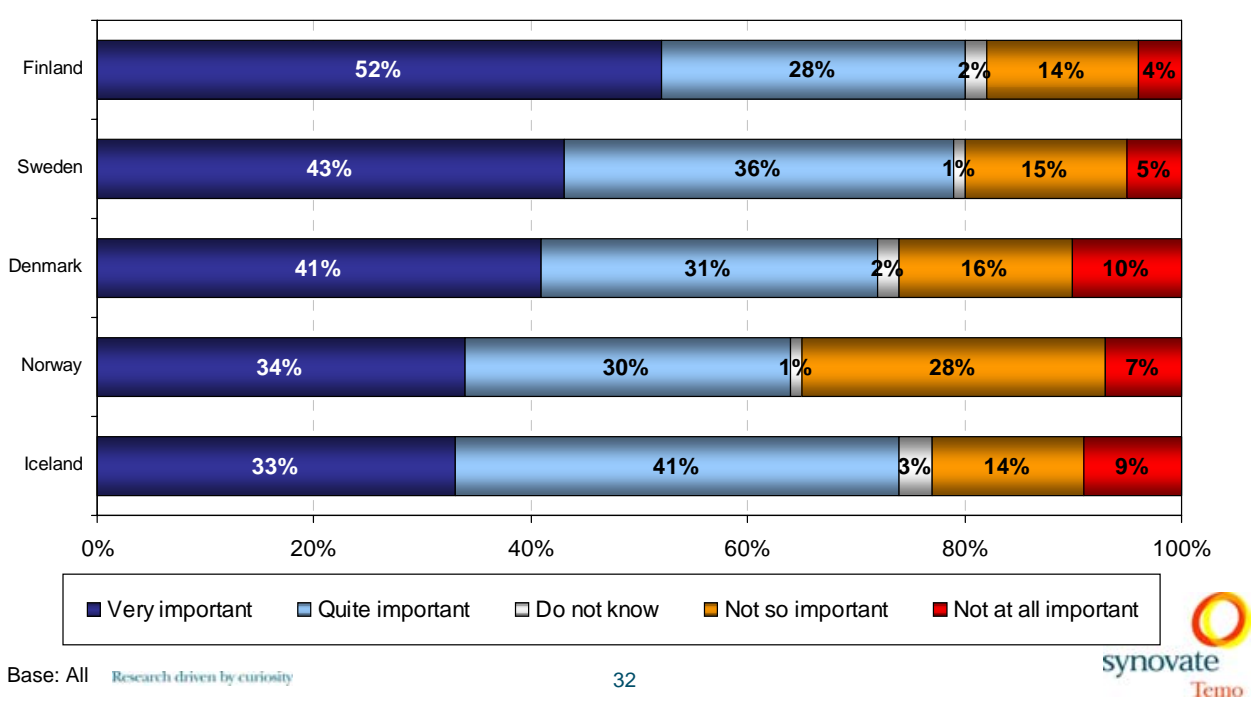




\section{The introduction of regulations relating to the minimum print size in order to facilitate legibility}

O 16-29 and 30-44 years of age find the issue significantly less important in Finland $-21 \%$ and $41 \%$ compared with $52 \%$ totally. 45-59 and 60+ years of age find the issue significantly more important $-68 \%$ and $77 \%$ compared with $52 \%$ totally.

O Men, 16-29 and 30-44 years of age find the issue significantly less important in Sweden - $36 \%, 21 \%$ and $33 \%$ compared with $43 \%$ totally. Women, 4559 and 60 + years of age find the issue significantly more important $-49 \%$, $49 \%$ and $64 \%$ compared with $43 \%$ totally.

O 16-29 and 30-44 years of age find the issue significantly less important in Denmark - $25 \%$ and $30 \%$ compared with $41 \%$ totally. 45-59 and 60+ years of age find the issue significantly more important - $50 \%$ and $54 \%$ compared with $41 \%$ totally.

O 16-29 and 30-44 years of age find the issue significantly less important in Norway $-17 \%$ and $22 \%$ compared with $34 \%$ totally. $45-59$ and $60+$ years of age find the issue significantly more important $-46 \%$ and $51 \%$ compared with $34 \%$ totally.

O Men, 16-29 and 30-44 years of age find the issue significantly less important in Iceland- $29 \%, 20 \%$ and $27 \%$ compared with $33 \%$ totally. Women, 4559 and $60+$ years of age find the issue significantly more important $-37 \%$ $43 \%$ and $50 \%$ compared with $33 \%$ totally.

That compulsory labelling information is always laid out in the same format on all packages

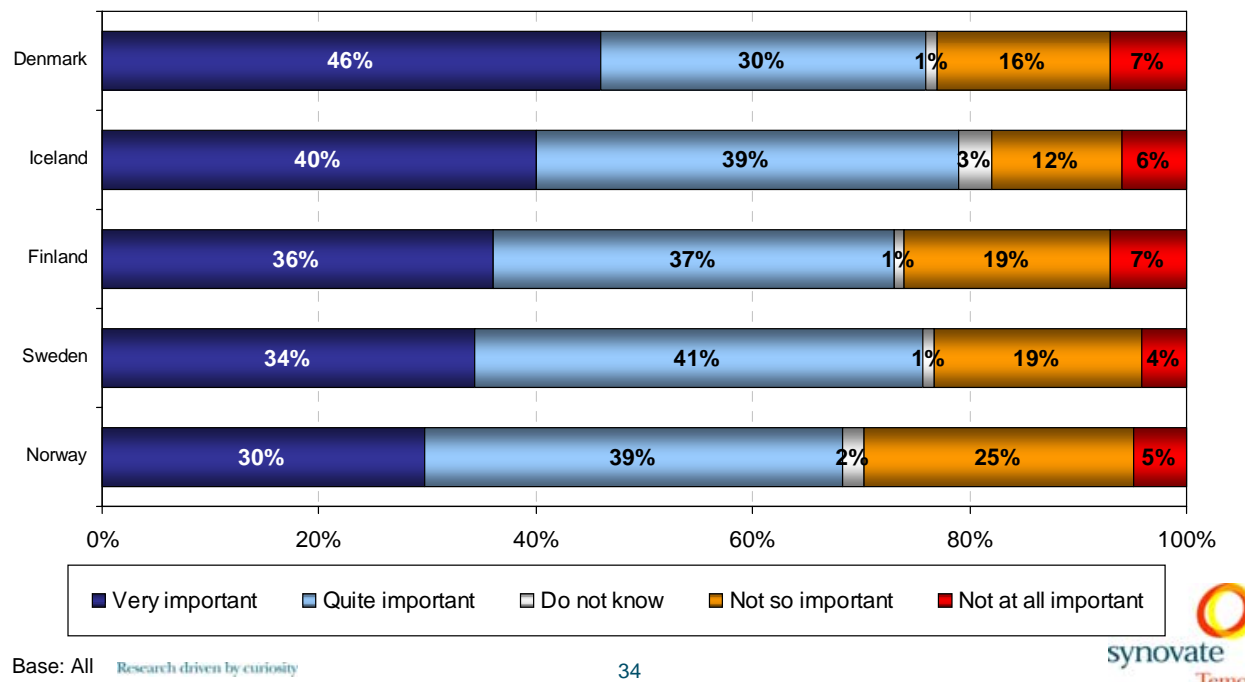




\section{That compulsory labelling information is always laid out in the same format on all packages}

There are no significant differences in Denmark.

O 16-29 years of age find the issue significantly less important in Iceland $24 \%$ compared with $40 \%$ totally. $45-59$ years of age find the issue significantly more important - $50 \%$ compared with $40 \%$ totally.

O 16-29 years of age find the issue significantly less important in Finland $24 \%$ compared with $36 \%$ totally. $45-59$ and $60+$ years of age find the issue significantly more important $-42 \%$ and $43 \%$ compared with $36 \%$ totally.

O 16-29 years of age find the issue significantly less important in Sweden $24 \%$ compared with $34 \%$ totally. $60+$ years of age find the issue significantly more important - $46 \%$ compared with $34 \%$ totally.

O 16-29 and 30-44 years of age find the issue significantly less important in Norway $-22 \%$ and $24 \%$ compared with $30 \%$ totally. 60 + years of age find the issue significantly more important $-39 \%$ compared with $30 \%$ totally.

That compulsory labelling information is always printed in the same place on all packages

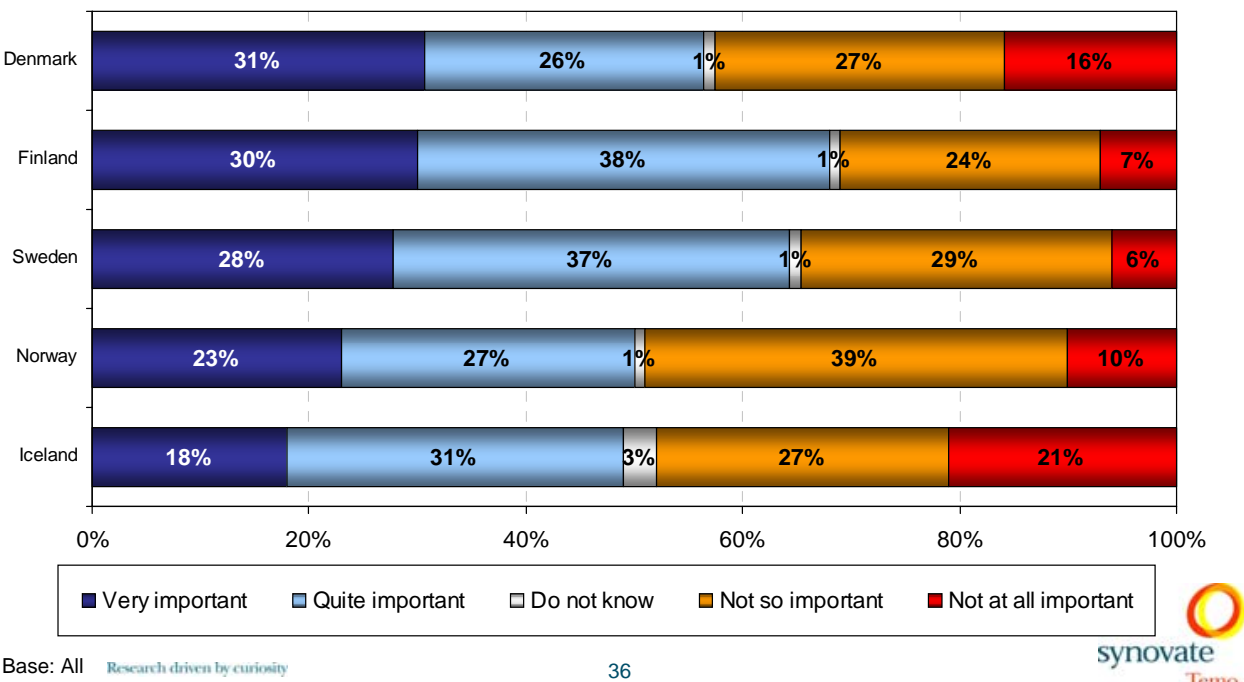




\section{That compulsory labelling information is always printed in the same place on all packages}

O 16-29 and 30-44 years of age find the issue significantly less important in Denmark - $19 \%$ and $24 \%$ compared with $31 \%$ totally. 60 + years of age find the issue significantly more important $-42 \%$ compared with $31 \%$ totally.

O 16-29 years of age find the issue significantly less important in Finland $14 \%$ compared with $30 \%$ totally. $45-59$ and $60+$ years of age find the issue significantly more important $-37 \%$ and $42 \%$ compared with $30 \%$ totally.

O 16-29 years of age find the issue significantly less important in Sweden $19 \%$ compared with $28 \%$ totally. 60 + years of age find the issue significantly more important $-42 \%$ compared with $28 \%$ totally.

O $60+$ years of age find the issue significantly more important in Norway $33 \%$ compared with $23 \%$ totally.

O 16-29 years of age find the issue significantly less important in Iceland $10 \%$ compared with $18 \%$ totally. $45-59$ and $60+$ years of age find the issue significantly more important $-22 \%$ and $30 \%$ compared with $18 \%$ totally.

\section{Limiting the number of authorized languages on packages}

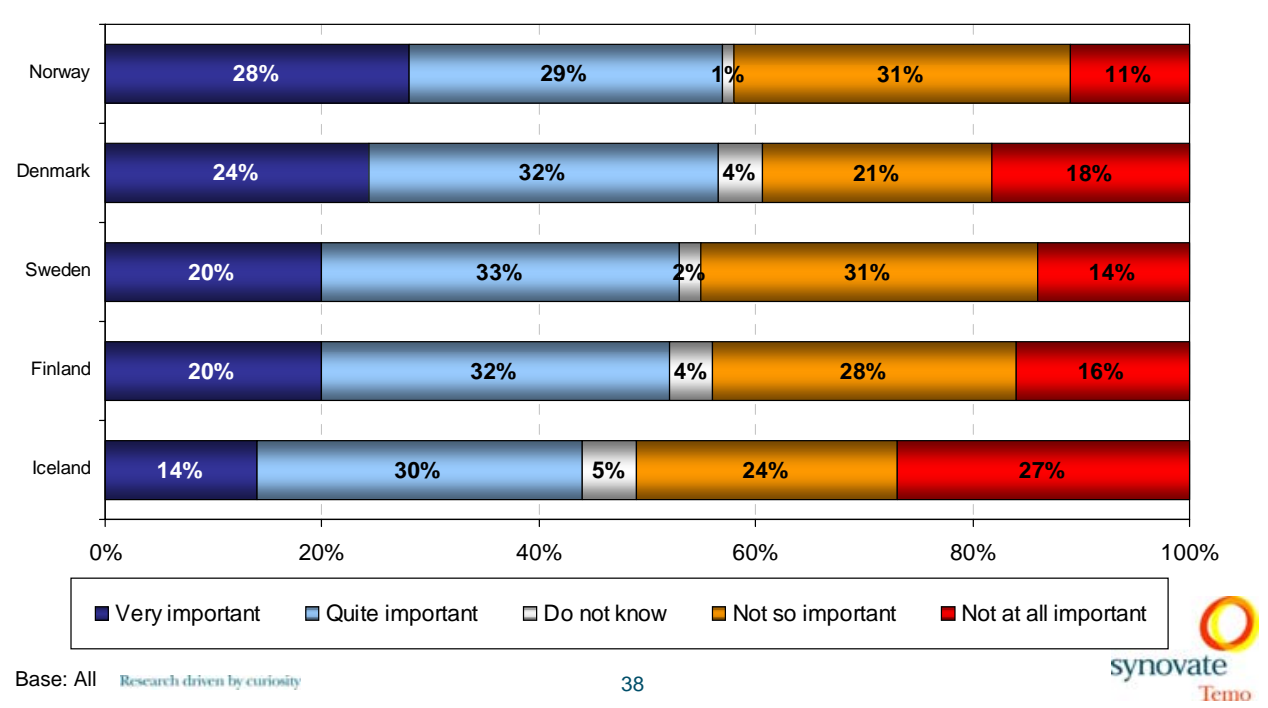




\section{Limiting the number of authorized languages on packages}

O $16-29$ years of age find the issue significantly less important in Norway $17 \%$ compared with $28 \%$ totally. 60 + years of age find the issue significantly more important - $35 \%$ compared with $28 \%$ totally.

O 16-29 years of age find the issue significantly less important in Denmark $16 \%$ compared with $24 \%$ totally. $45-59$ years of age find the issue significantly more important - $29 \%$ compared with $24 \%$ totally.

O 30-44 years of age find the issue significantly less important in Sweden $13 \%$ compared with $20 \%$ totally. 60 + years of age find the issue significantly more important - $29 \%$ compared with $20 \%$ totally.

O 16-29 years of age find the issue significantly less important in Finland $9 \%$ compared with $20 \%$ totally. $60+$ years of age find the issue significantly more important - $30 \%$ compared with $20 \%$ totally.

O $16-29$ years of age find the issue significantly less important in Iceland $8 \%$ compared with $14 \%$ totally. 60 + years of age find the issue significantly more important - $23 \%$ compared with $14 \%$ totally.

How important are the following for you to be able to access the information on food packaging?

O The introduction of regulations relating to the minimum print size in order to facilitate legibility is a popular idea with consumers in all five Nordic countries.

O Consumers also appreciate the idea that compulsory labelling information is always laid out in the same format on all packages.

O In general this question is not so important to the younger age group and vice versa for the older age group. 


\section{Question 4}

Today certain items of information are compulsory on food packaging and must be clearly stated, for example regarding beef, wheat-flour and prawns. A proposal has been put forward which aims to replace this with new types of pictures and symbols instead of printed text in Swedish/Norwegian/ Finnish/ Danish/Icelandic.

What is your opinion of this proposal? Do think it is ....?

Replace compulsory printed information with pictures and symbols

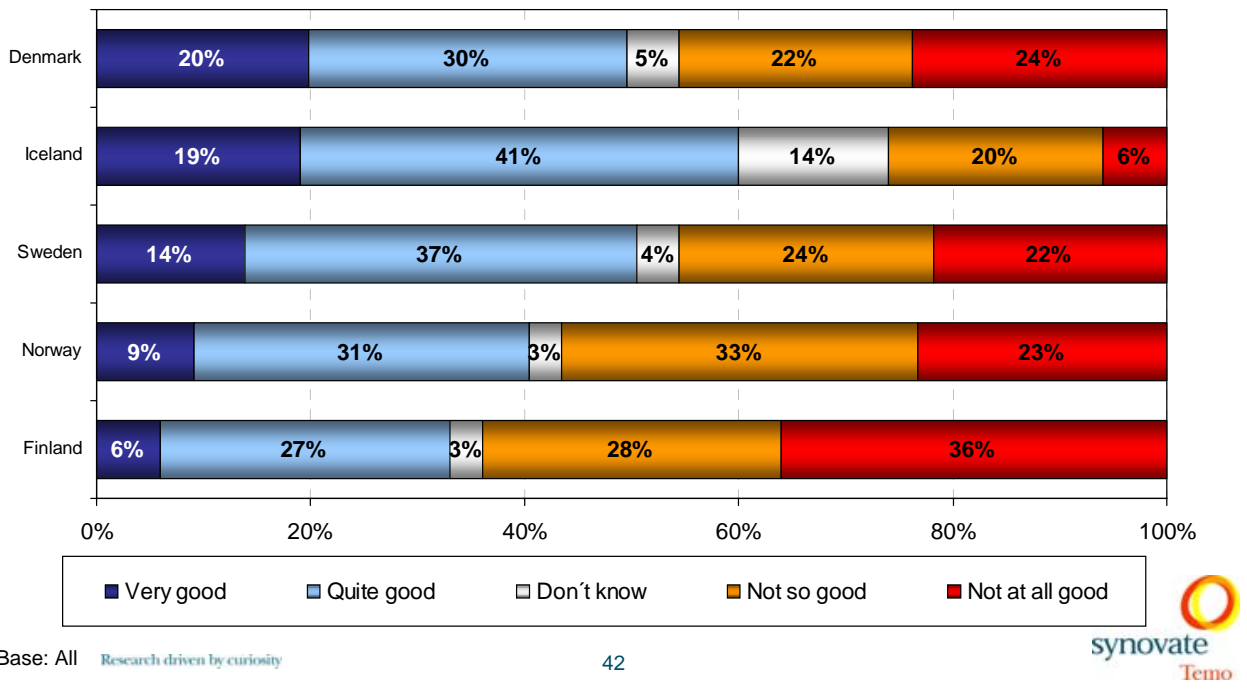




\section{Replace compulsory printed information with pictures and symbols}

O There are no significant differences in Denmark.

$O$ In Iceland men agree with this suggestion at a significantly lower level - $15 \%$, and vise versa for women - $23 \%$ compared with $19 \%$ totally.16-29 years of age find the suggestion quite good - $51 \%$ compared with $41 \%$.

0 In Sweden men and 60 + years of age do not find this suggestion good at all - $26 \%$ and $27 \%$ compared with $22 \%$ in total. The opposite goes for women and 30-44 years of age - $18 \%$ and $15 \%$ compared with $22 \%$ totally.

0 There are no significant differences in Norway.

$O$ In Finland 45-59 years of age find the suggestion not especially good to a lower extent - $22 \%$, and vice versa for $16-29$ years of age - $34 \%$ compared with $28 \%$ totally.

\section{Replace compulsory printed information with pictures and} symbols

O Consumers have an undecided or sceptical attitude towards this proposal

O Consumers in Sweden and Denmark are undecided

O Consumers in Norway and in Finland have a negative attitude.

O Iceland is the only country where consumers have a positive attitude to this idea

$O$ It is recommended that this question is further investigated, for example as follows:

- Explain what symbols mean, what they would look like etc.

- Show what kind of text would be replaced with symbols 


\section{Question 5}

Certain types of food products are marked with the country in which the finished product is

manufactured. However, no information about the country of origin of the raw materials exists.

What is your opinion about that type of marking?

Would you say that it is...?

...no information about the country of origin of the raw materials exists...

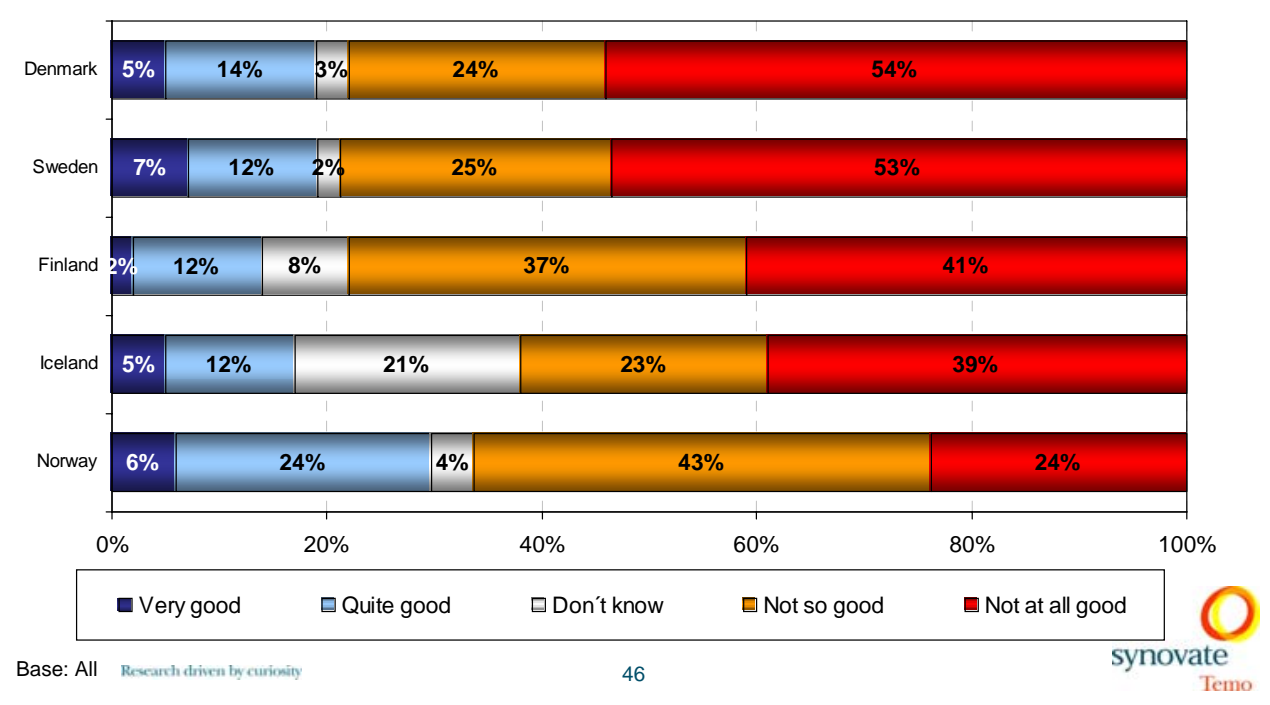




\section{...no information about the country of origin of the raw materials exists - Nordic countries}

O 16-29 years of age find the issue significantly less important in Denmark - $41 \%$ compared with $54 \%$ totally.

O 16-29 years of age find the issue significantly less important in Sweden $-73 \%$ compared with $79 \%$ totally. $45-59$ years of age find the issue significantly more important - $85 \%$ compared with $79 \%$ totally.

O 16-29 years of age find the issue significantly less important in Finland - $26 \%$ compared with $41 \%$ totally. $45-59$ and $60+$ years of age find the issue significantly more important - $50 \%$ and $54 \%$ compared with $41 \%$ totally.

O 16-29 years of age find the issue significantly less important in Iceland $-27 \%$ compared with $39 \%$ totally. 45-59 years of age find the issue significantly more important - $49 \%$ compared with $39 \%$ totally.

O 45-59 years of age find the issue significantly more important - $29 \%$ compared with $24 \%$ totally.

...no information about the country of origin of the raw materials exists...

O This is a uniform answer from all the Nordic countries. The majority of the consumers think that it is not good that you do not see what country the characterizing ingredients of the product come from. 


\section{Question 6}

How important is it that we know the country which the primary products in certain types of food come from. Would you say...?

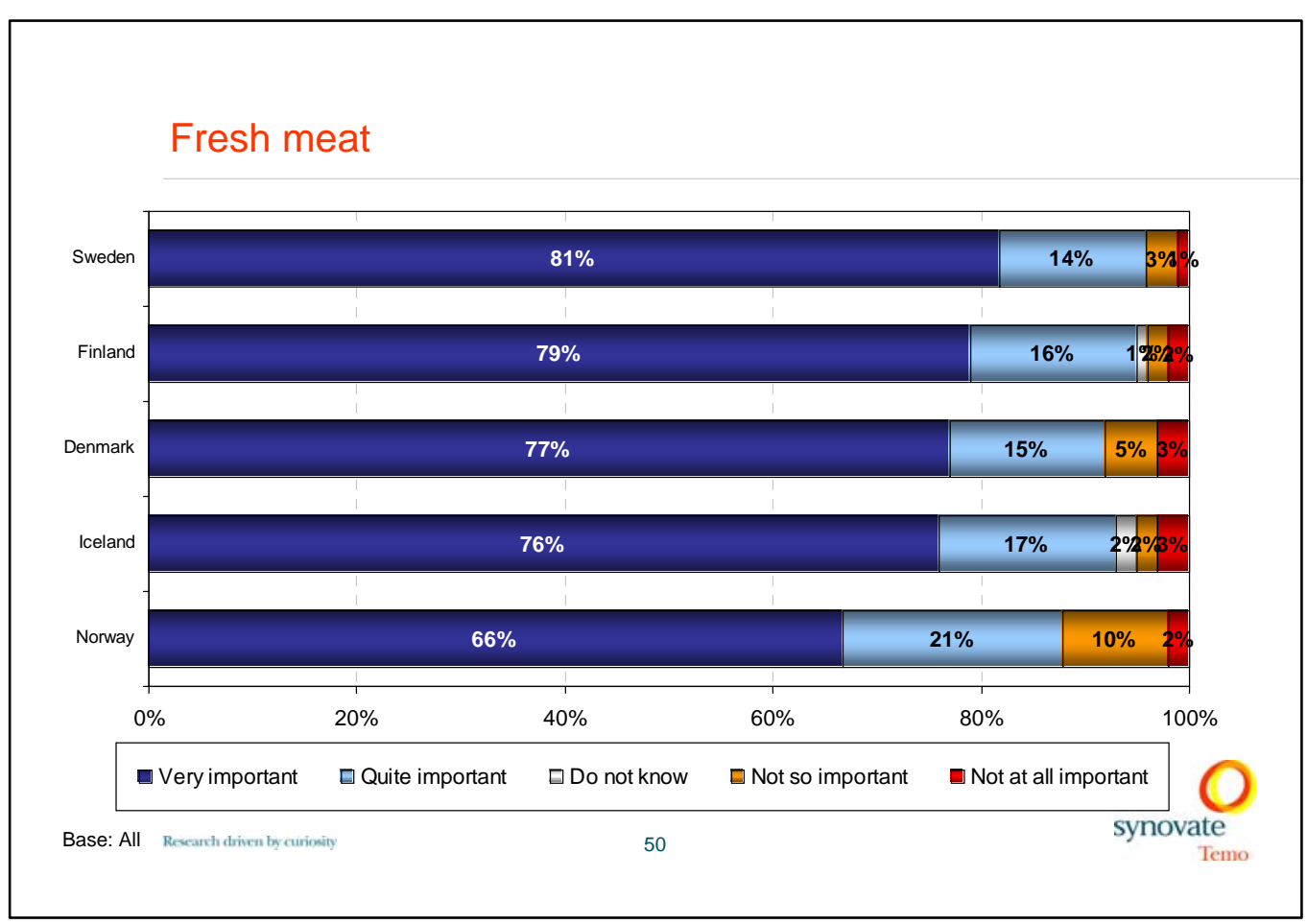




\section{Fresh meat- Nordic countries}

O Men find the issue significantly less important in Sweden - $75 \%$ compared with $81 \%$ totally. Women find the issue significantly more important $-88 \%$, compared with $81 \%$ totally.

O Men and 16-29 years of age find the issue significantly less important in Finland $-73 \%$ and $73 \%$ compared with $79 \%$ totally. Women find the issue significantly more important - $86 \%$ compared with $79 \%$ totally.

$O$ Men and 16-29 years of age find the issue significantly less important in Denmark $-72 \%$ and $70 \%$ compared with $77 \%$ totally. Women and $45-59$ years of age find the issue significantly more important $-82 \%$ and $82 \%$ compared with $77 \%$ totally.

O Men and 16-29 years of age find the issue significantly less important in Iceland $-71 \%$ and $64 \%$ compared with $76 \%$ totally. Women, 45-59 and $60+$ years of age find the issue significantly more important $-82 \%, 84 \%$ and $88 \%$ compared with $76 \%$ totally.

O 16-29 years of age find the issue significantly less important in Norway $57 \%$ compared with $66 \%$ totally. $60+$ years of age find the issue significantly more important $-72 \%$ compared with $66 \%$ totally.

\section{Meat products such as smoked ham - Nordic countries}

Sweden

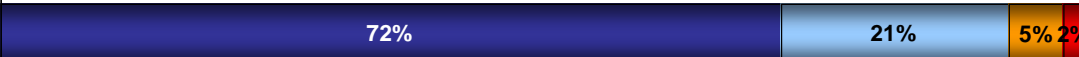

Finland

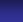

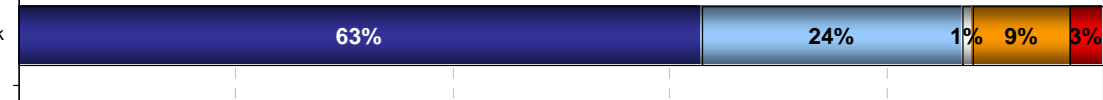

Nonway

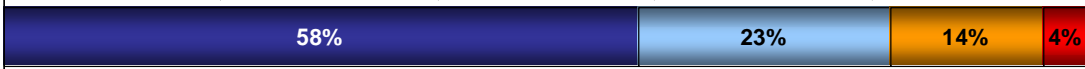

Iceland

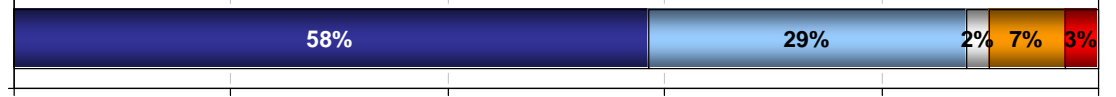

\begin{tabular}{llllll}
\hline $0 \%$ & $20 \%$ & $40 \%$ & $60 \%$ & $80 \%$ & $100 \%$
\end{tabular}

$\square$ Very important $\square$ Quite important $\quad \square$ Do not know $\quad \square$ Not so important $\quad \square$ Not at all important 


\section{Meat products such as smoked ham - Nordic countries}

O Men find the issue significantly less important in Sweden - $63 \%$ compared with $72 \%$ totally. Women find the issue significantly more important $-80 \%$, compared with $72 \%$ totally.

O Men and 16-29 years of age find the issue significantly less important in Finland $-64 \%$ and $60 \%$ compared with $71 \%$ totally. Women find the issue significantly more important $-78 \%$ compared with $71 \%$ totally.

$O$ Men and 16-29 years of age find the issue significantly less important in Denmark - $55 \%$ and $50 \%$ compared with $63 \%$ totally. Women and 45-59 years of age find the issue significantly more important $-70 \%$ and $72 \%$ compared with $63 \%$ totally.

0 Men and 16-29 years of age find the issue significantly less important in Norway - $53 \%$ and $42 \%$ compared with $58 \%$ totally. Women, 45-59 and $60+$ years of age find the issue significantly more important $-63 \%, 70 \%$ and $68 \%$ compared with $58 \%$ totally.

$O$ Men and 16-29 years of age find the issue significantly less important in Iceland - $53 \%$ and $41 \%$ compared with $58 \%$ totally. Women and $60+$ years of age find the issue significantly more important $-64 \%$ and $65 \%$ compared with $58 \%$ totally.

The meat in sausage - Nordic Countries

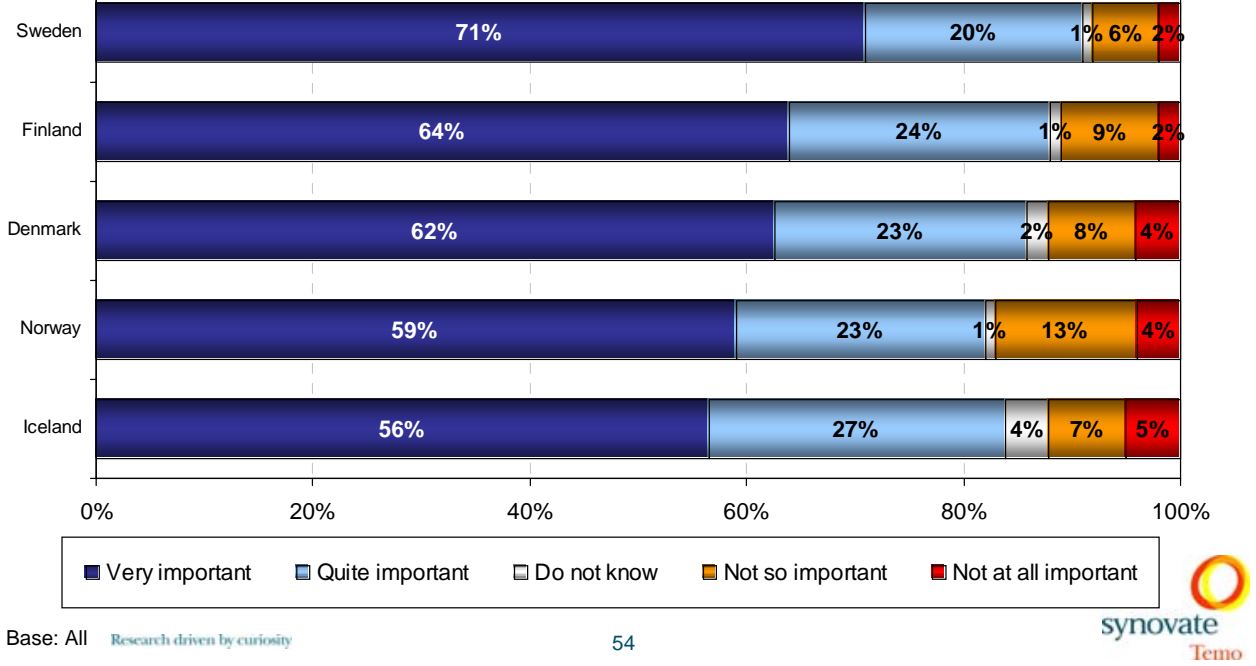




\section{The meat in sausage - Nordic countries}

O Men find the issue significantly less important in Sweden - $63 \%$ compared with $71 \%$ totally. Women find the issue significantly more important $-80 \%$, compared with $71 \%$ totally.

O Men and 16-29 years of age find the issue significantly less important in Finland $-58 \%$ and $50 \%$ compared with $64 \%$ totally. Women, 45-59 and 60 +years of age find the issue significantly more important - $70 \%, 71 \%$ and $73 \%$ compared with $64 \%$ totally.

$O$ Men and 16-29 years of age find the issue significantly less important in Denmark $-55 \%$ and $47 \%$ compared with $62 \%$ totally. Women and 45-59 years of age find the issue significantly more important - $69 \%$ and $73 \%$ compared with $62 \%$ totally.

$O$ Men and 16-29 years of age find the issue significantly less important in Norway $-53 \%$ and $46 \%$ compared with $59 \%$ totally. Women and $60+$ years of age find the issue significantly more important $-64 \%$ and $66 \%$ compared with $59 \%$ totally.

$O$ Men and 16-29 years of age find the issue significantly less important in Iceland $-52 \%$ and $37 \%$ compared with $56 \%$ totally. Women, 45-59 and $60+$ years of age find the issue significantly more important $-63 \%, 70 \%$ and $68 \%$ compared with $58 \%$ totally.

The meat contained in a pizza

Sweden

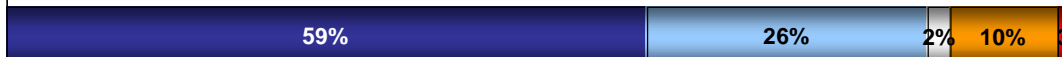

Finland

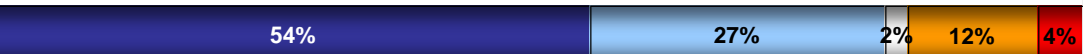

Denmark

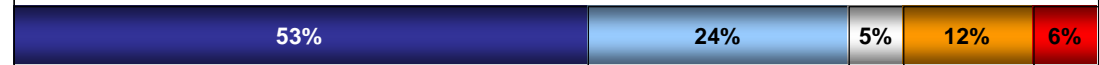

Nonay

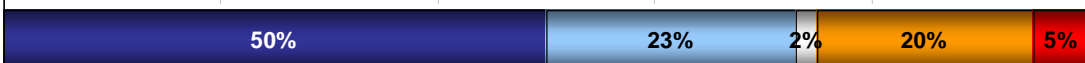

-

land

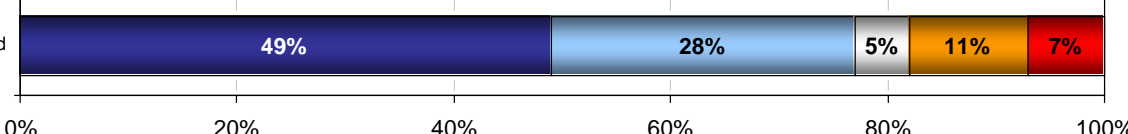

\begin{tabular}{llllll}
\hline $0 \%$ & $20 \%$ & $40 \%$ & $60 \%$ & $80 \%$ & $100 \%$
\end{tabular}

$\square$ Very important $\quad \square$ Quite important $\quad \square$ Do not know $\quad \square$ Not so important $\quad \square$ Not at all important 


\section{The meat contained in a pizza - Nordic countries}

O Men find the issue significantly less important in Sweden - $46 \%$ compared with $59 \%$ totally. Women and $45-59$ years of age find the issue significantly more important $-70 \%$, compared with $65 \%$ totally.

O $60+$ years of age find the issue significantly less important in Finland - $45 \%$ compared with $54 \%$ totally.

O Men and 16-29 years of age find the issue significantly less important in Denmark - $46 \%$ and $45 \%$ compared with $53 \%$ totally. Women and 45-59 years of age find the issue significantly more important $-60 \%$ and $63 \%$ compared with $53 \%$ totally.

O Men and 16-29 years of age find the issue significantly less important in Norway $-43 \%$ and $37 \%$ compared with $50 \%$ totally. Women find the issue significantly more important $-57 \%$ compared with $50 \%$ totally.

$O$ Men and 16-29 years of age find the issue significantly less important in Iceland $-42 \%$ and $28 \%$ compared with $49 \%$ totally. Women, 45-59 and $60+$ years of age find the issue significantly more important - $56 \%, 63 \%$ and $59 \%$ compared with $49 \%$ totally.

\section{Fresh fruit, berries and vegetables}

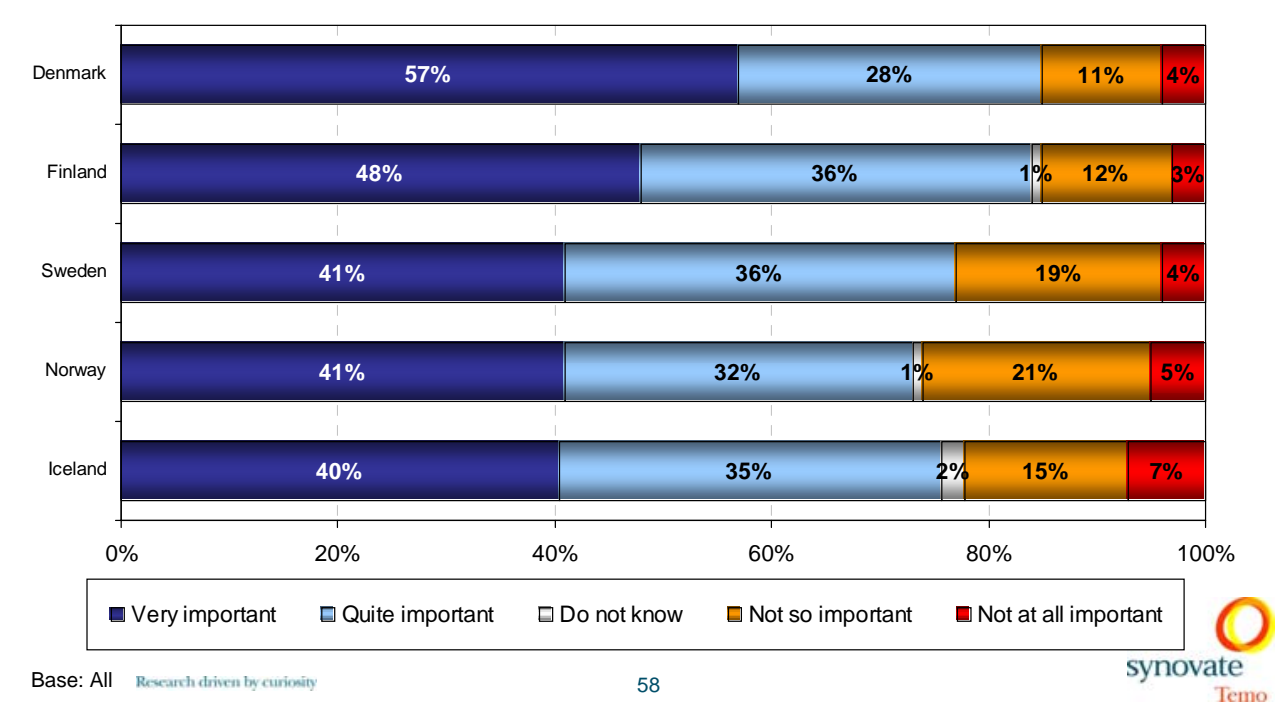




\section{Fresh fruit, berries and vegetables - Nordic countries}

Men and 16-29 years of age find the issue significantly less important in Denmark - 51 and $41 \%$ compared with $57 \%$ totally. Women and $60+$ years of age find the issue significantly more important $-62 \%$ and $68 \%$, compared with $57 \%$ totally.

O 16-29 years of age find the issue significantly less important in Finland $38 \%$ compared with $48 \%$ totally.

O 16-29 years of age find the issue significantly less important in Sweden $-26 \%$ compared with $41 \%$ totally. 60 + years of age find the issue significantly more important - $52 \%$ compared with $41 \%$ totally.

060 + years of age find the issue significantly more important in Norway $51 \%$ compared with $41 \%$ totally.

O Men and 16-29 years of age find the issue significantly less important in Iceland $-34 \%$ and $30 \%$ compared with $40 \%$ totally. Women and 4559 years of age find the issue significantly more important $-47 \%$ and $49 \%$ compared with $40 \%$ totally.

Deep-frozen fruit and berries sweetened with sugar

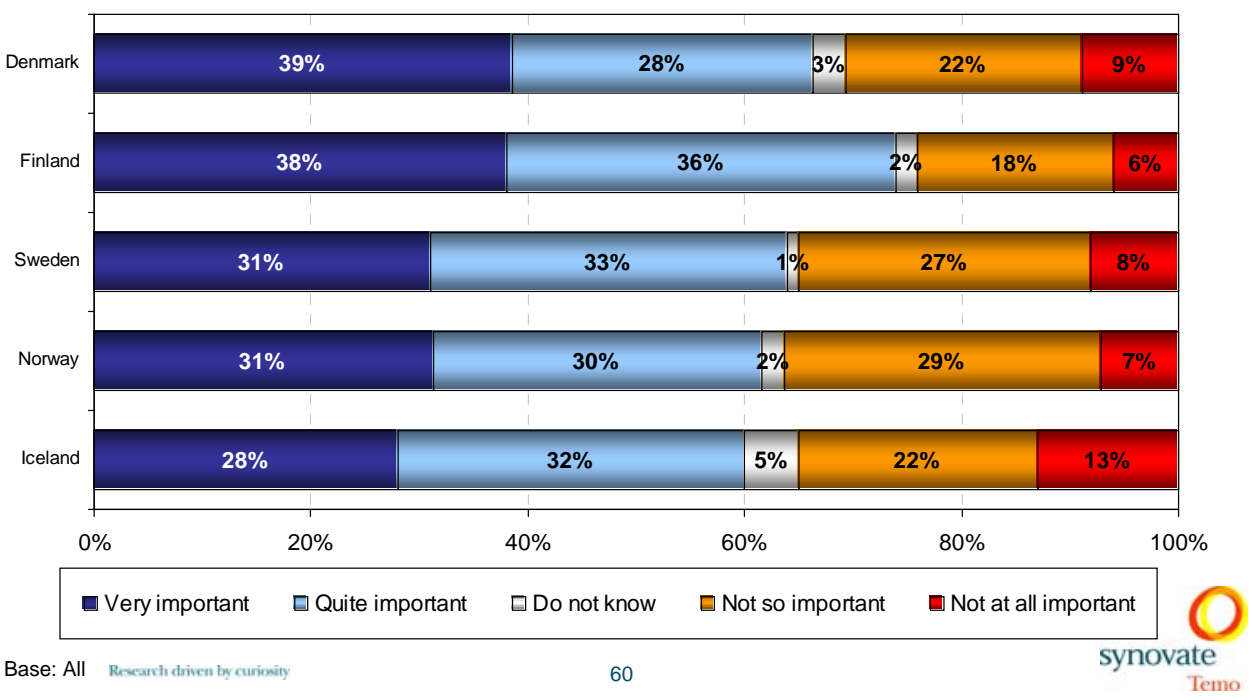




\section{Deep-frozen fruit and berries sweetened with sugar - Nordic countries}

O Men and 16-29 years of age find the issue significantly less important in Denmark - 31 and $18 \%$ compared with $39 \%$ totally. Women, 45-59 and $60+$ years of age find the issue significantly more important - $45 \%, 46 \%$ and $49 \%$, compared with $39 \%$ totally.

$O$ Men and 16-29 years of age find the issue significantly less important in Finland - $38 \%$ and $21 \%$ compared with $48 \%$ totally. Women, 45-59 and $60+$ years of age find the issue significantly more important $-45 \%, 50 \%$ and $45 \%$, compared with $38 \%$ totally.

Men and 16-29 years of age find the issue significantly less important in Sweden $-26 \%$ and $17 \%$ compared with $31 \%$ totally. Women and $60+$ years of age find the issue significantly more important $-35 \%$ and $41 \%$ compared with $31 \%$ totally.

O 16-29 years of age find the issue significantly less important in Norway - $19 \%$ compared with $31 \%$ totally. $60+$ years of age find the issue significantly more important $-39 \%$ compared with $31 \%$ totally.

O 16-29 years of age find the issue significantly less important in Iceland - $14 \%$ compared with $28 \%$ totally. 45-59 and $60+$ years of age find the issue significantly more important $-40 \%$ and $39 \%$ compared with $28 \%$ totally.

Fruit and berries in jams and marmalade

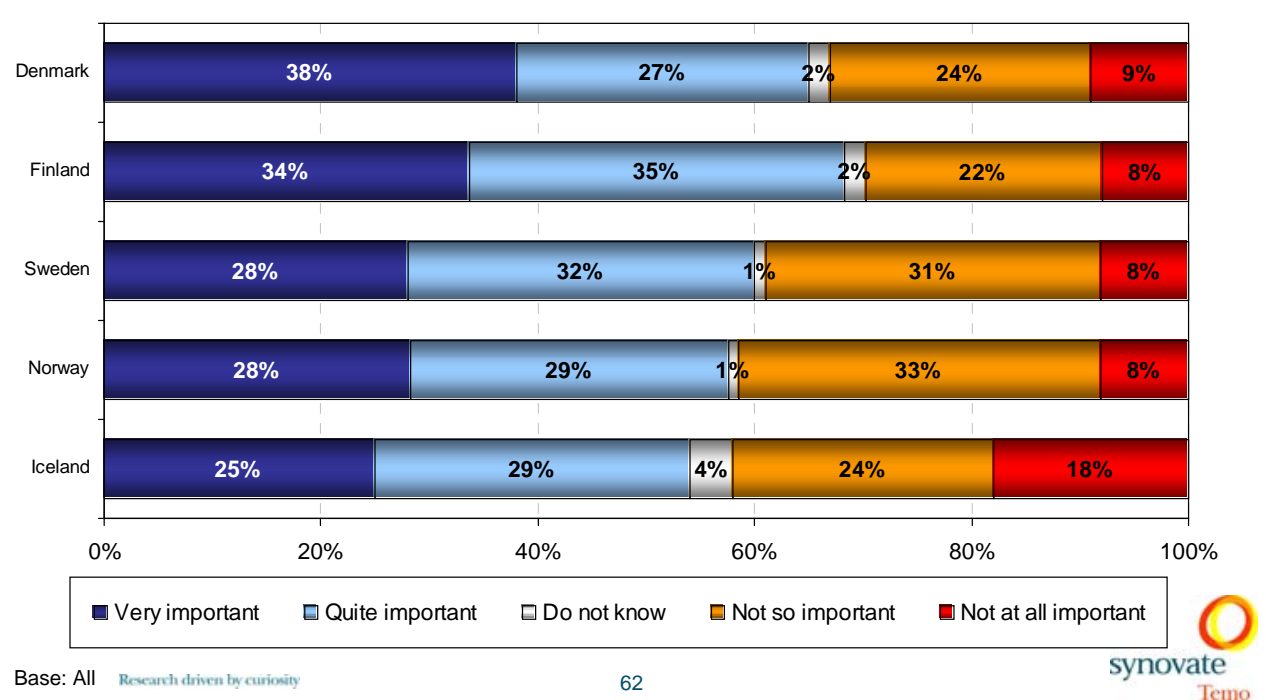




\section{Fruit and berries in jams and marmalade - Nordic countries}

O Men and 16-29 years of age find the issue significantly less important in Denmark - 31 and $18 \%$ compared with $39 \%$ totally. Women, 45-59 and $60+$ years of age find the issue significantly more important - $45 \%, 46 \%$ and $49 \%$, compared with $39 \%$ totally.

0 Men and 16-29 years of age find the issue significantly less important in Finland - $38 \%$ and $21 \%$ compared with $48 \%$ totally. Women, $45-59$ and $60+$ years of age find the issue significantly more important $-45 \%, 50 \%$ and $45 \%$, compared with $38 \%$ totally.

$O$ Men and 16-29 years of age find the issue significantly less important in Sweden $-26 \%$ and $17 \%$ compared with $31 \%$ totally. Women and $60+$ years of age find the issue significantly more important $-35 \%$ and $41 \%$ compared with $31 \%$ totally.

O 16-29 years of age find the issue significantly less important in Norway - $19 \%$ compared with $31 \%$ totally. $60+$ years of age find the issue significantly more important $-39 \%$ compared with $31 \%$ totally.

O 16-29 years of age find the issue significantly less important in Iceland - $14 \%$ compared with $28 \%$ totally. 45-59 and $60+$ years of age find the issue significantly more important $-40 \%$ and $39 \%$ compared with $28 \%$ totally.

Rescearch driven by curiosity

\section{Each separate kind of vegetable in deep-frozen mixed vegetables}

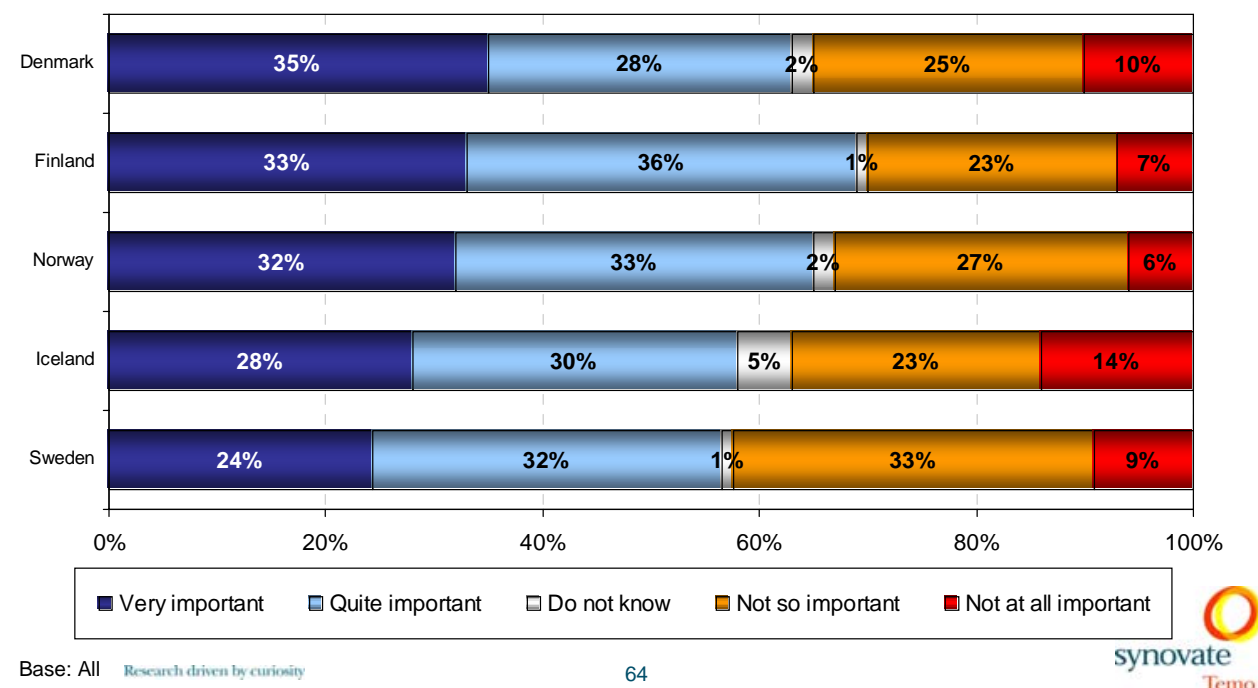




\section{Each separate kind of vegetable in deep-frozen mixed vegetables- Nordic countries}

O 16-29 years of age find the issue significantly less important in Denmark - $16 \%$ compared with $35 \%$ totally. 45-59 and 60 + years of age find the issue significantly more important $-41 \%$ and $44 \%$ compared with $35 \%$ totally.

$O$ Men and 16-29 years of age find the issue significantly less important in Finland $-28 \%$ and $15 \%$ compared with $33 \%$ totally. Women, $45-59$ and $60+$ years of age find the issue significantly more important $-38 \%, 39 \%$ and $45 \%$, compared with $33 \%$ totally.

O 16-29 years of age find the issue significantly less important in Norway - $18 \%$ compared with $32 \%$ totally. $60+$ years of age find the issue significantly more important $-44 \%$ compared with $32 \%$ totally.

$O$ Men and16-29 years of age find the issue significantly less important in Iceland $-23 \%$ and $14 \%$ compared with $28 \%$ totally. Women, $45-59$ and $60+$ years of age find the issue significantly more important $-32 \%, 37 \%$ and $37 \%$ compared with $28 \%$ totally.

O 16-29 years of age find the issue significantly less important in Sweden - $17 \%$ compared with $24 \%$ totally. 60 + years of age find the issue significantly more important $-30 \%$ compared with $24 \%$ totally.

Fruit or berries in jams used in the making of cakes

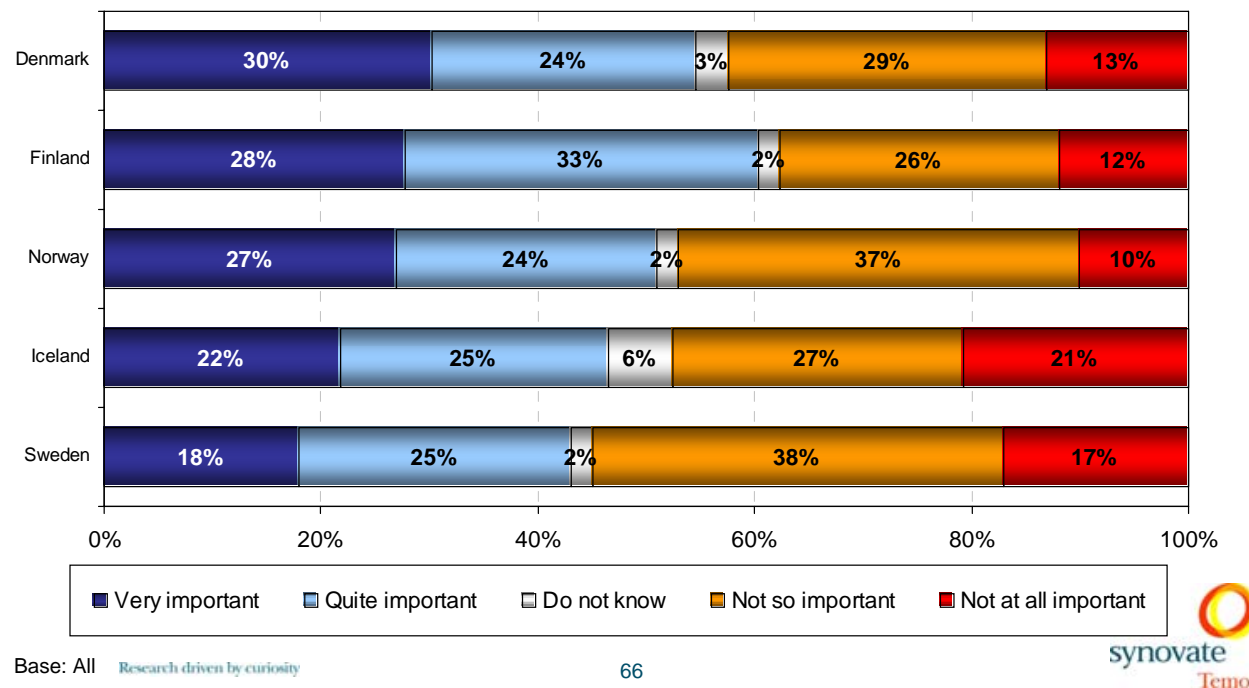




\section{Fruit or berries in jams used in the making of cakes - Nordic countries}

O 16-29 years of age find the issue significantly less important in Denmark - 19 compared with $30 \%$ totally. 45-59 and $60+$ years of age find the issue significantly more important $-36 \%$ and $36 \%$ compared with $30 \%$ totally.

O 16-29 and 30-44 years of age find the issue significantly less important in Finland $-17 \%$ and $21 \%$ compared with $28 \%$ totally. 45-59 and $60+$ find the issue significantly more important $-35 \%$ and $38 \%$ compared with $28 \%$ totally.

O 16-29 years of age find the issue significantly less important in Norway - $15 \%$ compared with $27 \%$ totally. 60 + years of age find the issue significantly more important $-35 \%$ compared with $27 \%$ totally.

O 16-29 years of age find the issue significantly less important in Iceland - $11 \%$ compared with $22 \%$ totally. $45-59$ and 60 + years of age find the issue significantly more important $-29 \%$ and $32 \%$ compared with $22 \%$ totally.

O 16-29 years of age find the issue significantly less important in Sweden - $9 \%$ compared with $18 \%$ totally. 60 + years of age find the issue significantly more important $-24 \%$ compared with $18 \%$ totally.

\section{Information on which country the primary products originate from}

$O$ In Fresh meat, Smoked ham and the Meat in a sausage it is considered to be very important to know the country which the primary products come from.

$O$ It is also considered to be important to know what country the meat in a pizza originates from - Denmark puts fresh fruit and vegetables ahead of this and it is also considered to be important to know where the meat in a pizza originates from.

O To have the knowledge where fresh/ raw primary products - above all fresh/raw meat, followed by fresh vegetables and fruit originates from is considered to be of most importance.

o To have the information on where the primary products originate from in a processed product e.g. jam is also considered to be important, but not as important as when the product is fresh/raw. 


\section{Question 7}

Today there are different ways of displaying country of origin. With regard to meat it could be the country of birth, the country where the animal was raised, where it has been slaughtered, where it has been butchered or the country where the finished product was manufactured and packaged.

With regard to fruit and vegetables the product might display the country where the fruit or the vegetables were grown or the country where the finished product was manufactured or packaged.

In order to make it possible to make a conscious choice regarding a certain food product, how do you consider the country of origin should be shown on the package?

\section{How should the country of origin be shown on the} package?

Top-of-mind - Sweden

1. Country of origin

"Det ska vara ursprungslandet som ska stå på förpackningen."

"Ursprunget är viktigare än slutprodukten."

2. Where the food was grown/ picked

"Frukt o grönt: det ska stå var de kommer ifrån,

där de odlats. Det är så olika hur det besprutas.

"Med frukt och grönsaker vill jag veta vart de

odlats."

3. Where the animal was born, bred

"Det land där djuret är uppfött är allra viktigast.

butiken"

"När det gäller kött ska det framgå var djuret är

Where the products were packed/ produced "Det skall stå i vilket land varan har förpackats." "Det ska stå var den färdiga varan är förpackat"

5. "There should be information about everything"

"Borde ju stå allt var det är tillverkat hela kedjan. Borde stå hela vägen från vilket land alla produkter är tillverkade till vilket land som produkten."

"Alla led ska finnas med, från födelseland till "Alla led

6 . Where the animal was slaughtered butchered

7. Country (text/symbol/flag)

8. Clearly printed information, easy to read

How should the country of origin be shown on the package? 
How should the country of origin be shown on the package?

Top-of-mind - Norway

1. Country of origin

"Meget viktigt att opprinnelseland er oppgitt."

6. Ingredients, contents

"Det kan stå opprinneldseland på prisetikketen."

7. Happy with how it is now

2. Clear information in print, easy to read "Godt synlig, at det er lett å se.."

"Angis med tydelig skrift."

8. There should be information about everything

3. Where the product was produced "Hvor det er pakket og produsert." "Produsent må også merkes."

4. Where the animal was born/bred "Hvor grisen har vokst opp." "Hvor det är dyrket rett og slett"

5. Symbol with flag of the country of origin "Ha et flagg på pakken?."

"Det dyret kommer ifra med flagg."

How should the country of origin be shown on the package?

\section{How should the country of origin be shown on the} package?

Top-of-mind - Denmark

1. Country of origin

" Der skal stå hvilket land og gerne fremhævet! Oprindelses landet er vigtigt det er en kvalitet en varer hvor den kommer fra. Det er central information."

"Der skal stå oprindelses landet med skrift"

2. Where the animal was born, bred/where the

fruit was grown/picked

"Hvor dyret er opvokset. Hvor grøntsagerne er

"Der hvor det er opvokset eller plukket er

3. Country where the food was packed/ produced

" Bare hvor der er pakker og produceret" " Produktionsland og forarbejdningsland bør tydeligt markeres"

4. There should be information about everything

" Man skal mærke både med land og med region, supermarkedets modtagelsesdato, høstdato.

" Hvor det har været hende hele vejen"

5. Country marked with flag, symbol

"Landets navn, sted betegnelse, flag"

"Flag hvor man kan se hvilke land produktet
kommer fra."

6. Where the animal was slaughtered $l$ butchered

7. It should say if it is Danish

8. Clear information, easy to read in print

How should the country of origin be

shown on the package? 


\section{How should the country of origin be shown on the package? \\ Top-of-mind - Finland}

1. Country of origin

"The country of origin is the most important thing."

" When it comes to meat products it is good to know where the animal in question was bred, the

2. Where it was produced/ where it was packed

"Country where it was packaged - packager is

"Both are equally important : the country of
origin and country of manufacture"

3. Where the animal was born/ bred "Country where the animal was born and bred." "information about where the animal was born and bred"

4. Clear information in print, easy to read "In Finnish and clearly visible"

" easy to read, even without glasses" 5. Should be information about everything "The whole chain is very important to know." " All the information could be there but really: do
we have any real choice?"
6. Country (flag, symbol)

7. Where the animal was slaughtered/ butchered

8. Where the fruit was grown/ picked

How should the country of origin be shown on the package?

\section{How should the country of origin be shown on the} package?

Top-of-mind - Iceland

1. Country of origin

"Country of origin, birthplace of the animal.

"Origin, would be good to know. Where the animal

6. Where the animal was slaughtered/ butchered

2. Where it was produced/ packed "Where final packaging took place." "Where produced and packaged"

7. I don't care / It is OK as it is

3. Where the animal was born/ bred "Country where the animal was born and bred." "I think there should be information on where the product was grown/bred"

4. Where the fruit was grown/ picked "Fruit where grown and processed."

5. There should be information about everything

"Everything mentioned should be stated. Country of birth, where bred, slaughtered, packaged and produced and country where grown.

"All the information could be there but really: do we have any real choice?"

8. Clear information in print, easy to read

How should the country of origin be shown on the package? 


\section{Some comments in general}

O The information on a package tends to come from what I would like to have personally in order to be able to make a choice for myself so that I will not become ill.

- Best-before-date

- Contents of ingredients

- Country which the product or contents originate from

O Country which the product or contents originate from is of special importance when it comes to fresh products and above all fresh/raw meat.

O A minimum text size is considered very important as well.

O A general comment is also that women and the elderly age groups find issues of this kind more important. The same goes for age groups and level of education - higher level finds the issues more important. 


\section{References}

Nordisk Ministerråd (1998), Food Labelling. TemaNord 1998:557.

http://www.norden.org/pub/sk/showpub. asp?pubnr $=1998: 577$

Nordisk Ministerråd (2001), Forbrugernes krav til fødevaremærkning og vareinformation. TemaNord 2001:573. http://www.norden.org/pub/sk/showpub. asp?pubnr=2001:573

Nordisk Ministerråd (2002), Nordic Policy toward the Labelling of Foods. TemaNord 2002:589.

http://www.norden.org/pub/sk/showpub. asp?pubnr=2002:589

Nordisk Ministerråd (2004), Nutrition Labelling: Nordic Recommendations Based on Consumer Opinions. Tema-
Nord 2004:508.

http://www.norden.org/pub/sk/showpub. asp?pubnr $=2004: 508$

Nordisk Ministerråd (2004), Ethical labelling of food. ANP 2004:741

http://www.norden.org/pub/sk/showpub. asp?pubnr=2004:741

Nordisk Ministerråd (2004), Seminar Ethical Information about Food. TemaNord 2004:545.

http://www.norden.org/pub/sk/showpub. asp?pubnr=2004:545

Nordisk Ministerråd (2006), Food Labelling - Report from a Nordic Seminar. TemaNord (2006: 601). http://www.norden.org/pub/sk/showpub. asp?pubnr=2006:601

\section{References to other relevant reports}

Märkning och marknadsföring av livsmedel - rapport från Nordisk workshop. TemaNord 1998:516 http://www.norden.org/pub/sk/showpub. asp?pubnr=1998:516

Matvarer - kun for majoriteten? TemaNord 2001:555.

http://www.norden.org/pub/sk/showpub. asp?pubnr $=2001: 555$
Andel konsumenter som förstår ett urval av viktiga märkningsuppgifter Totalrapport dec 2005/ jan 2006, LUI Marknadsinformation AB 2006-02-14

English version: Quantification: proportion of consumers who understand selected Important labelling information. Full report Dec 2005/Jan 2006 www.slv.se/templates/SLV_NewsPage.a spx?id=11825 


\section{Sammanfattning}

Denna rapport sammanfattar resultaten från en kvantitativ konsumentundersökning om konsumenters attityder eller uppfattningar när det gäller märkning av livsmedel. Undersökningen genomfördes efter initiativ från livsmedelsmyndigheterna i de fem nordiska länderna; Sverige, Norge, Danmark, Finland och Island. Projektet har finansierats av Nordiska Ministerrådet.

Syftet med konsumentundersökning var att få ny och uppdaterad kunskap om nordiska konsumenters behov, önskemål och prioriteringar beträffande märkning och information om livsmedel. Resultatet av konsumentundersökningen ska bidra med information, kunskap och faktaunderlag inför den kommande översynen av EU: s märkningsbestämmelser (bl.a. märkningsdirektivet).

Synovate Temo i Sverige har på uppdrag från Livsmedelsverket genomfört konsumentundersökningen. Frågorna i undersökningen har tagits fram i ett samarbete mellan en projektgrupp med representanter från livsmedelsmyndigheterna i de nordiska länderna och konsulterna från Synovate Temo i Sverige. Undersökningen genomfördes med en blandning av rangordningsfrågor och öppna frågor. Frågorna handlade om:

- vilken information som konsumenter helst vill se på förpackningen

- hur viktig olika typer av information är för konsumenter

- vad som är viktigt för att konsumenter ska kunna hitta, läsa och förstå information som finns på förpackningar

- konsumenternas inställning till förslag om att ersätta obligatorisk konsumentinformation, som idag finns i text på förpackningar, med bilder och/eller symboler

- konsumenternas inställning till befintlig märkning av ursprung

- behov av märkning av ursprung för råvaror i olika livsmedel

- hur ursprung bör anges på livsmedelsförpackningar

Intervjuerna genomfördes inom ramen för en så kallad omnibusundersökning med allmänheten i respektive land. Drygt 1000 intervjuer genomfördes i varje land med ett slumpmässigt och representativt urval ur allmänheten, 16 år och äldre. Intervjuerna genomfördes under perioden 16 oktober-26 oktober, 2006.

De preliminära resultaten från undersökningen presenterades på ett nordiskt seminarium 20-21 november 2006 som hölls i Oslo, Norge (TemaNord 2006:601). 


\section{Sammanfattning av resultat}

Man bör beakta att resultaten i undersökningen till viss del ger en ögonblicksbild av vad konsumenterna i de nordiska länderna är upptagna av vid den tiden som undersökningen genomfördes. Hade undersökningen genomförts ett halvår innan eller ett halvt år senare skulle man kunna ha fått annorlunda svar i vissa frågor. I Danmark har det under senaste året varit stor uppmärksamhet kring flera fall där ompaketering av gammalt kött har förekommit, i Sverige har ursprungsmärkning diskuterats mycket det sista året och i Norge har sockerdebatten varit aktuell. Konsumenternas svar som sammanfattas nedan återspeglar i flera fall de mest mediaaktuella frågorna i respektive länder.

Enligt resultaten från undersökningen bör uppgifter eller information om ingredienser, näringsinnehåll, bäst före datum och ursprungsland tydligt finnas med på livsmedelsförpackningen. Detta är den information nordiska konsumenter anser viktigast att finna i märkningen för att kunna göra medvetna val när de handlar mat.

Svaren visar att bland de frågor konsumenterna anser viktigast, när de själva prioriterar eller rangordnar mellan olika märkningsuppgifter, är uppgifter om näringsinnehåll och ursprungsland viktig information. Detta är uppgifter som i dagsläget inte är obligatoriska. Resultatet är i linje med den rådande utvecklingen när det gäller konsumenters önskemål om information på livsmedelsförpackningar för att kunna göra medvetna val när de handlar. Vidare är det mycket intressant att information om ingredienser prioriteras högst när konsumenterna själva rangordnar uppgifterna i denna öppna fråga, trots att detta inte varit en mediaaktuell fråga.

Utifrån en lista med nio olika märkningsuppgifter anses information om bäst före datum viktigast i samtliga nordiska länder (97\%). Uppgifter om ingredienser (90\%), vilket slags livsmedel det är (89\%) och näringsinnehåll (83\%) anses också som mycket viktigt eller viktig information av konsumenterna i alla nordiska länder. Även uppgifter om ämnen som kan ge allergier (79\%) och ursprungsland (78\%) är viktiga frågor.

Etisk information, till exempel om miljö, djurskydd och mänskliga rättigheter, anses vara viktiga frågor för nordiska konsumenter men minst viktigt (61\%) bland den information som konsumenter anser bör finnas på själva förpackningen för att kunna göra ett medvetet val av livsmedel.

Införande av regler om minsta textstorlek på förpackningar för att kunna öka läsbarheten är ett populärt förslag hos konsumenter i samtliga nordiska länder (74\%). Nordiska konsumenter välkomnar även förslaget om att obligatoriska märkningsuppgifter alltid ska ställas upp på samma sätt på alla förpackningar (74\%).

Förslag om införande av regler för att obligatoriska märkningsuppgifter alltid ska finnas på samma ställe på alla förpackningar samt att begränsa antalet tillåtna språk på förpackningarna är signifikant mindre viktigt för nordiska konsumenter. 
I allmänhet visar undersökningen att dessa frågor inte är så viktiga för den yngre åldersgruppen och vice versa för den äldre åldersgruppen. Detta är kanske något att fundera på med tanke på den starkt åldrande befolkningen i Europa.

Nordiska konsumenter är obestämda eller skeptiska till förslaget om att ersätta obligatoriska märkningsuppgifter i text med nya sorters bilder och symboler. $47 \%$ av de nordiska konsumenterna tycker det är ett mycket bra eller bra förslag emedan $48 \%$ anser det att det inte är särskilt bra eller inte är alls bra. Särskilt konsumenter i Norge och Finland har en tydlig negativ hållning till detta förslag. Svenska och danska konsumenter är obestämda.

Enbart isländska konsumenter har en positiv hållning till förslaget om att ersätta obligatoriska märkningsuppgifter med bilder och symboler.

Det bör dock beaktas att denna undersökning genomfördes med telefonintervjuer. Det rekommenderas därför att denna fråga bör undersökas närmare i fokusgrupper där det är möjligt att förklara konsumenterna vad sådana bilder och symboler betyder, hur de skulle kunna komma att se ut, visa vilka uppgifter eller texter som symbolerna kommer att ersätta etc.

När det gäller ursprungsmärkning visar undersökningen tydligt att nordiska konsumenter är missnöjda med att råvarornas ursprung inte finns på förpackningen. Detta är ett entydigt svar från alla nordiska länderna: En majoritet av konsumenterna (73\%) anser att det inte är särskilt bra eller inte alls bra at det inte är möjligt att få information om vilket land den karaktersgivande ingrediensen eller råvaran kommer från.

Uppgifter om vilket ursprungsland råvaran kommer från anses som mycket viktigt eller viktigt när det gäller färskt kött (92\%), köttprodukter som t.ex. rökt skinka (88\%) och kött i korven (86\%). Det är också viktigt för nordiska konsumenter att få information om ursprunget till såväl köttet i en pizza (79\%) som färsk frukt och grönsaker (79\%). Även uppgifter om råvarornas ursprung beträffande sammansatta produkter som till exempel sylt anses viktigt men inte så viktigt som för färska eller obearbetade produkter.

Resultatet av den öppna frågan om hur ursprungsland bör anges på förpackningen visar att nordiska konsumenter i allmänhet inte har någon avancerad eller sofistikerad uppfattning om vilka specifika uppgifter om ursprung de verkligen vill ha. Det är dock uppenbart att ursprungsmärkning är viktigt för nordiska konsumenter även om många konsumenter inte kan skilja mellan olika sätt att ange ursprung på förpackningarna.

Ett stort antal konsumenter har även i detta sammanhang påpekat behovet av tydlig och lätt läsbar information på livsmedelsförpackningar. Svaren i denna undersökning understryker behovet av förtydliga den befintliga definitionen av ursprung samt att fastställa gemensamma kriterier för angivelse av ursprung eller ursprungsland. 